\title{
Grand Challenges in Construction Management
}

\author{
Zhen Chen* \\ Department of Architecture, Faculty of Engineering, University of Strathclyde, Glasgow, United Kingdom
}

Keywords: abductive reasoning, built environment, construction management, body of knowledge, digital innovation, intelligent system, megaproject management

This article is written for the launch of the specialty section on construction management at the Frontiers in Built Environment. This new specialty section opens an on-line platform for academics and practitioners in the subject field to share valuable experiences and findings from innovative research and development as well as practices, which focus on the management of people/workforce, product/production, and processes across built environment project stages, including development and construction, operation and maintenance, as well as demolition and redevelopment, under considerations on the dependability and productivity of construction management services. In this article, the writer presents his humble opinions limited from experiences from academic research and professional services around the world in the past three decades. The topics derived on grand challenges in construction management are gigantic in terms of their coverages, but may have huge impacts on professional development in both short and longer term. Discussions presented here on grand challenges in construction management

OPEN ACCESS

Edited by:

Borja Garcia de Soto,

New York University Abu Dhabi, United Arab Emirates

Reviewed by:

Takashi Kaneta,

Kyoto University, Japan Laura Florez,

Northumbria University,

United Kingdom

*Correspondence:

Zhen Chen

z.chen@live.com

Specialty section:

This article was submitted to Construction Management, a section of the journal

Frontiers in Built Environment

Received: 20 July 2018

Accepted: 25 February 2019

Published: 02 April 2019

Citation:

Chen Z (2019) Grand Challenges in

Construction Management.

Front. Built Environ. 5:31.

doi: 10.3389/fbuil.2019.00031 consist of four parts to respectively focus on an initial cognitive framework of the construction management body of knowledge (CMBOK), intelligence pervasive construction management systems, interdisciplinary digital innovation, and solutions for performance enhancement in megaproject delivery. The research methodology that support the writer to describe the four grand challenges includes literature review, comparison study, site observation, and system architecture analysis and development. It was the writer's initial abductive reasoning to identify the four grand challenges in construction management through an extensive literature review, which was based on national and regional strategies for the construction industry from the world top economies. Some key references relating to these four major topics are collected to support discussions in this article. It is expected that this article could contribute to the debate as well as research and development in construction management in terms of continuous technical enhancements on project-oriented performance and value regardless the scope, the location, and the time associated and concerned. As the study was conducted through abductive reasoning, this article should have its limitation on the coverage to all grand challenges in construction management, and this should leave many unanswered questions for further exploratory research.

\section{INTRODUCTION}

Construction management (CM) is an important field of management practice oriented research into related issues at both the macro and micro sphere across the entire life cycle $(\mathrm{CIOB}, 2010)$ of the built environment. The macro sphere of CM can generally cover all management related issues on the built environment across its life-cycle stages; for example, the industry wide statistics, analysis and projections on codes and standards, building information management, procurement and contracts, supply network, workforce productivity, and workplace health and safety, etc. at national, regional and/or international level. The micro sphere of CM, on the other hand, covers specific issues relating to project delivery at various work stages; for example, project specific study on feasibility, cost plan, design justification, process schedule, risk assessment, quality and traceability 
assurance, productivity analysis, post occupancy evaluation, and service level agreements, etc. The cross-stage process of $\mathrm{CM}$ makes it possible to conduct inter-connected professional services for clients to have maximum value from investment.

Since the principles of scientific management was put forward by Taylor (1911), the theory has profound influence to the evolving theory of management science in over 10 decades, and there has been a significant theoretical evolution in the management world. As summarized by Jones and George (2016), the evolution of management theories in the past century has demonstrated a trans-disciplinary development across five fundamental theories, including the scientific management theory, the administrative management theory, the behavioral management theory, the management science theory, and the organizational environment theory. This theoretical evolution in management science has eventually formed an entire body of knowledge (BOK) for management practice in various professional fields across industry sectors, and consequently it has continuously provided strong theoretical support to $\mathrm{CM}$ oriented research and practice.

The purpose of this article is to describe a recent research undertaken by the author to identify grand challenges in construction management in response to present national/regional strategies for the construction industry in world top economies, and to inform decision making on further research and development as well as learning and training with regard to the enhancement of dependability and productivity in construction management services. In order to justify the need for this research, the author has looked into the gigantic accumulation of related resources as collected in not only civil engineering databases at ASCE (2019) and ICE (2019) but also multidisciplinary databases on the Web of Science platform (Clarivate, 2019), and the search term used is "challenges AND construction management." It has been found that there is limited number of publications related to this topic, and it looks there is currently no publication dedicating to a discussion on grand challenges in $\mathrm{CM}$ focused research and development. From this point of view, this article has the opportunity to fill the gap in research into construction management.

This article is based on the author's observations through academic research and professional services in related areas around the world over the past three decades. Based on a further review on grand challenges and strategic priorities for the construction sector in six world's major economies, including United States, China, Japan, Germany, United Kingdom, and European Union, four grand challenges that reflect national/regional strategic priorities were eventually derived as significant ones. Table $\mathbf{1}$ is used to clarify the reflection of four perceived grand challenges in construction management to existing strategic proprieties in these world's major economies. It's the author's opinion that these four grand challenges are responsive to those national/regional strategies and therefore could be useful with further discussions to inform further research and development in construction management with regard to the pursuit of national/international leadership in this subject field.
According to this simplified independent response to the national/regional strategic priorities for the construction sector in the six world's major economies, this article aims to provide further discussions on the four grand challenges, and focuses on Frontiers of Research and Development in Construction Management with regard to the increasing need for service dependability and productivity in the development and operation of the built environment in both short and a relative longer term. This article therefore covers four topics on the four grand challenges in relation to three identified managerial domains on people/workforce, product/production, and processes, respectively, in the provision of CM services.

In developing the contents of this article, the four grand challenges are used for its structure to cover the following specific discussions:

- The grand challenge on the development and use of a theoretical CMBOK framework and its contents in accordance with research and practice accumulated across disciplines over long term in the past,

- Two grand challenges, in response to the needs for intelligent management systems and interdisciplinary digital innovations respectively, in order to improve the performance of constructions management services, and

- The grand challenge on technical enhancement for construction management in megaproject delivery in order to promote best practices through large-scale construction management services.

The relevance of these topics to the three management domains derived from an extensive review on five main management theories (see Figure 1) is further described in Table 1. This qualitative analysis helped the author to make decision on topics to discuss grand challenges in construction management.

This article is based on the author' recent research through the use of two methods, including extensive literature review and qualitative comparison study, while his long-term experiences and observations in academic research and professional practices were also incorporated. In addition, this article has been thoroughly improved according to a huge amount of insightful comments given by reviewers.

In this article, the author uses terms, including the dependability of construction management services and the dependable built environment, to incorporate the need for dependability (Chen, 2017) at life-cycle stages of the built environment. According to the only three results from searching on Google as of 3 November 2018, the term dependable built environment was also used in practice by the Stonepay Construction in Canada. For the built environment, dependability (BSI, 2014) can be regarded as a collective term for time-related quality characteristics with regard to the ability to perform as and when required throughout the life cycle of either a product or a service. It is the author's assumption that the incorporation of dependability with the technical term of built environment on the product side and construction management on the service side can facilitate an 
TABLE 1 | Four topics on grand challenges in construction management.

\begin{tabular}{|c|c|c|}
\hline CM domains & Grand challenges and Strategic priorities for the construction sector in major economies & $\begin{array}{l}\text { Responsive grand } \\
\text { challenges in } \mathrm{CM}\end{array}$ \\
\hline People/workforce & $\begin{array}{l}\text { - Improving human-capital basis (EC, 2012) } \\
\text { - Develop skills capacity and capability (IPA, 2016) } \\
\text { - Improving the quality of consulting services (HURD, 2017) } \\
\text { - Building and maintaining the technical, financial, and managerial capacity necessary to ensure long-term infrastructure } \\
\text { sustainability (EPA, 2017) } \\
\text { - Increasing workforce skills (BEIS, 2018) } \\
\text { - Economic competitiveness and workforce (DOT, 2018) } \\
\text { - Modernization by improving intelligent client capability (LGA, 2018) }\end{array}$ & CM body of knowledge \\
\hline Product/production & $\begin{array}{l}\text { - Competition among construction enterprises (EC, 2012) } \\
\text { - Low carbon and sustainable construction (BIS, 2013) } \\
\text { - Enabling and driving whole-life approaches (IPA, 2016) } \\
\text { - Achieving a virtually climate-neutral building stock (BMUB, 2016) } \\
\text { - Initiatives on i-Construction to enhance productivity, and Development of new technologies such as those of artificial } \\
\text { intelligence (Al) (STI, 2017b) } \\
\text { - Promoting system standardization (HURD, 2017) } \\
\text { - Implementation of e-Construction methodology (FHWA, 2017) } \\
\text {-Life cycle and Preventive maintenance on infrastructure (DOT, 2018) } \\
\text { - Maximizing savings through a better understanding of how whole life cost and value improvements (LGA, 2018) } \\
\text { - The development and use of Al technologies (BMWi, 2018) }\end{array}$ & Intelligent CM system \\
\hline Processes & $\begin{array}{l}\text { - The performance of the value chain (EC, 2012) } \\
\text { - Smart construction and digital design (BIS, 2013) } \\
\text { - Increase the use of digital technology (IPA, 2016) } \\
\text { - Promoting industrial modernization (HURD, 2017) } \\
\text { - Innovative construction and infrastructure maintenance tech. (STI, 2017a) } \\
\text { - Expansion of ICT aided construction to raise efficiency on site (STI, 2017b) } \\
\text { - Promoting planning processes that support infrastructure sustainability (EPA, 2017) } \\
\text { - Development and commercialization of digital and manufacturing technologies (BEIS, 2018) } \\
\text { - Development and deployment of innovation (DOT, 2018) } \\
\text { - Enabling innovation including building information model/modeling/management (BIM) and off-site manufactured } \\
\text { solutions (LGA, 2018) }\end{array}$ & Digital innovation \\
\hline
\end{tabular}

integrated measure that can cover engineering and management aspects connecting to dependability characteristics, which can include adaptability, availability, construability, durability, maintainability, recoverability, reliability, health and safety, security, supportability, and sustainability, etc. It is the author's opinion that the use of dependability for both built environment as the product and its life-cycle oriented services can effectively integrate various interconnected considerations and decision making on people/workforce, products/production, and processes in construction management for quantified quality assurance across its whole life cycle oriented services in the built environment. While numerous cases have shown that a lack of dependability may have significantly adverse impact through rewordings on productivity, it is important to give priority to dependability in the pursuit of productivity in construction management.

It is the author's expectation for this article to be useful for not only colleagues working on innovative research and development in the subject field of construction management, but also the specialty section on construction management at the Frontiers in Built Environment to be part of longterm leadership development in research and development 


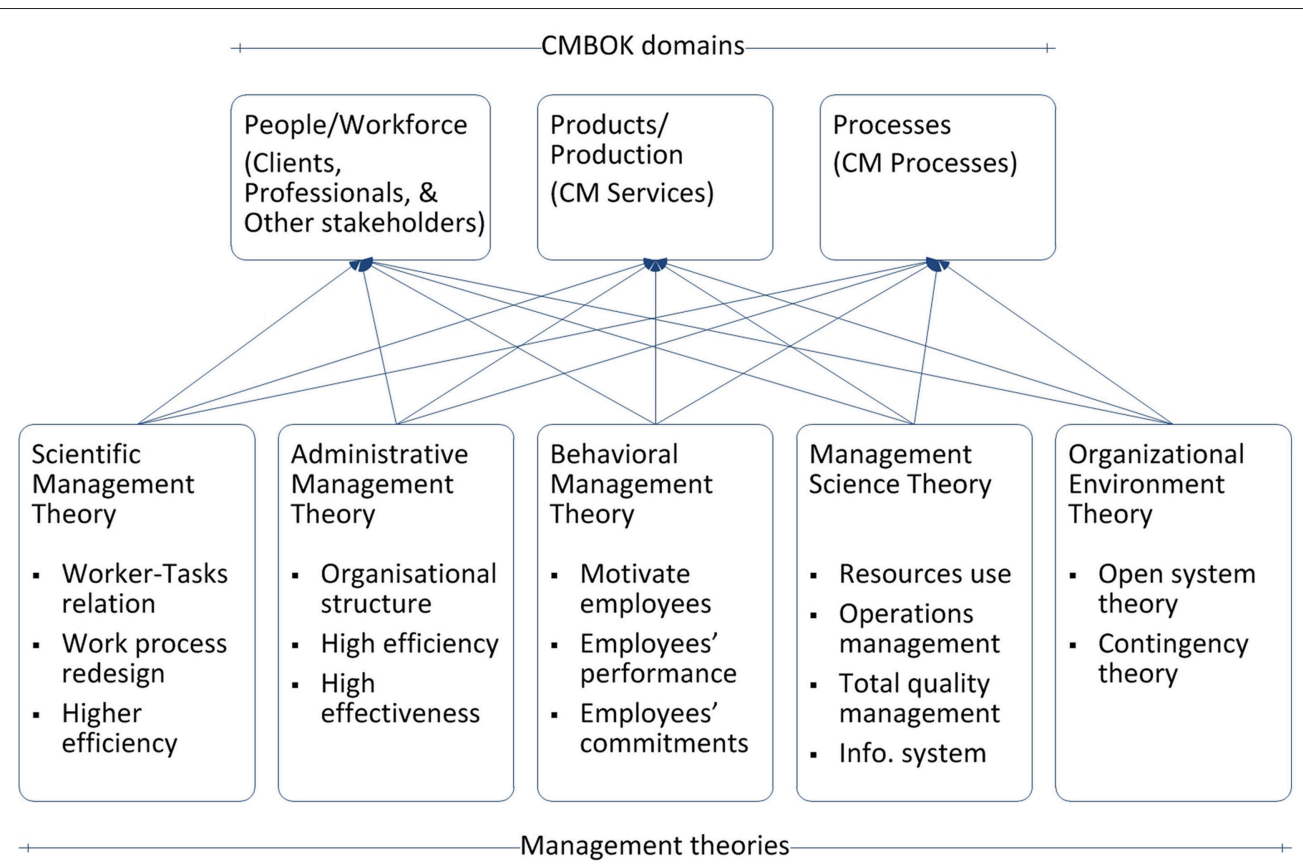

FIGURE 1 | Management domains of CMBOK interconnected with management theories.

for the construction management profession across the world. As the four described grand challenges were derived in response to current national/regional strategies for the construction sector in major economies, further research and development under the four grand challenges are also expected in order to timely and effectively support technical enhancements on both dependability and productivity in construction management services for the sustainable built environment.

\section{CONSTRUCTION MANAGEMENT BODY OF KNOWLEDGE (CMBOK)}

The first grand challenge to discuss is to establish a CMBOK, which can be useful for construction management oriented learning, practice, research and development in terms of both dependable professional services and continuous technical enhancements. Generally speaking, construction management is an elemental subject of the built environment discipline, and it is an essential professional service interactively connecting with other specific professions working inside the construction industry. It has extensive connections to other subject fields such as planning, design, and operation (CIOB, 2010) within the built environment sector, in addition to resources and manufacturing, computing and programming, transportation and supply management, legislations and governances from other adjunct sectors to support its work procedure at various stages. For professional construction management services, there are mature work procedures such as the definitive UK model Plan of Work (RIBA,
2013), the code of practice such as the CIOB (2014) Code of Practice for Project Management for Construction and Development, and regulations such as the Construction (Design and Management) Regulations 2015 (HSE, 2015) in the United Kingdom. Construction management is therefore a dedicated profession that provides services focusing on construction to satisfy both project-wide and industry-wide needs for professional management within the built environment.

\section{Management Domains}

The BOK for a specific subject field is generally essential and useful for both practice toward excellence and research for innovation. As a good example, the body of knowledge for project management (PMBOK) (PMI, 2017) has demonstrated the value of $\mathrm{BOK}$ in project management across industry sectors over the past two decades. It was originally published and continuously updated at the Project Management Institute (PMI, 2017) to guide practice in project management, and eventually adopted by the International Organization for Standardization (ISO, 2012) as an international standard for project management. In addition to professional guidance for general project management, PMI (2016) has continuously provided the extension to the $\mathrm{PMBOK}^{\circledR}$ Guide for construction management since 2003, and this provides useful reference to form the CMBOK. The author would like to determine $\mathrm{CMBOK}$ as a set of structured descriptions about professional knowledge and underpinned techniques to sustain dependable quality services of construction management at both macro and micro scale in the built environment.

In connection with the evolution of theories and technologies in engineering and management, the technical scope of 
construction management has been enlarged, and the delivered service focuses on enhanced dependence and efficiency across life-cycle work stages (CIOB, 2010). It is a matter of fact that an enormous amount of endeavors made by academics and practitioners in construction management worldwide is a huge contribution to form the $\mathrm{CMBOK}$, although there is currently not a definitive framework, such as the PMBOK (PMI, 2016, 2017) and the Civil Engineering Body of Knowledge (CEBOK) (ASCE, 2008, 2019), for construction management in both project-wide and industry-wide scale. It is therefore a big task for further research into the cognitive framework of $\mathrm{CMBOK}$ and its elements and contents with regard to three identified cognitive domains, including people, products and processes (See Figure 1), to foster innovations in a more effective way for not only the dependence and efficiency of this professional service in practice, but also quality higher education (Pellicer et al., 2013) and continuing professional development (CPD) (Chen et al., 2006b) for professionals and students, respectively.

For the three technical domains mentioned above on people/workforce, products/production, and processes in construction management, Figure $\mathbf{1}$ is used to clarify its origin by illustrating the connections between management theories (Jones and George, 2016) to three identified main management domains that can be used to structure the construction management body of knowledge (CMBOK). It summarizes five representative toolkits derived from management theories that can support construction management on three managerial domains, which cover people/workforce, products/production, and processes. These managerial domains are identified through an extensive review into the five management theories with regard to fundamental issues that they are dealing with. As described by Oakland and Marosszeky (2017) and Kajima (2018) based on need for best practices, these domains are essential for total construction management (TCM) that enables a comprehensive use of all contemporary management theories to tackle issues on workforce, production, and processes across project life cycle in the built environment. In theory, TCM can be used as a term for the provision of all types of specific construction management services together under one contract, in comparison with construction management that refers to professional services in a generic term.

It is profoundly meaningful for the CM profession to have a cognitive framework of the body of professional knowledge, like the one ASCE and PMI have been working on for continuous professional development and further research. There are several critical reasons to justify its importance with regard to its value for different stakeholders involved in construction management. For stakeholders such as construction contractors, it could be a useful guide to take the initiative under the blue ocean strategy (Kim and Mauborgne, 2004), which is defined as the simultaneous pursuit of differentiation and low cost to open up a new market space and create new demand, to develop outstanding expertise above horizontal competition. In other words, a bespoke BOK can ensure a sound development of expertise in providing professional services in one or more specific areas within an entire knowledge map. For clients who invest in the construction project, it is a useful benchmark for them to evaluate the performance of construction management at various project stages. In addition to its value for construction management practice, the cognitive framework of construction management body of knowledge can also be useful to inform higher education (Arditi and Polat, 2010; Nguyen et al., 2017), professional training, as well as academic and professional research in terms of well-scoped depth and long-term continuous professional development. It is therefore considerate to develop a cognitive framework of BOK for the construction management profession.

\section{Cognitive Domains}

The structure of CMBOK, as one particular focus of this article to promote an initiative development for the whole construction management profession, can be outlined by using related cognitive domains, also called knowledge areas or domains, as structural elements of professional knowledge for the framework. For the structure of $\mathrm{CMBOK}$, it therefore becomes critical to define its cognitive domains and their contents in order to establish such a framework of professional knowledge.

The definition of cognitive domains relies on a comprehensive coverage to both explicit and tacit knowledge (Dalkir, 2017), which is required for quality services in specific professional areas such as civil engineering, construction management, and project management, respectively. One particular effort to identify all cognitive domains relating to construction management is to review possible ones adopted in existing BOKs such as CEBOK (ASCE, 2008, 2019) and PMBOK (PMI, 2016, 2017) and to make holistically consolidated connections to construction management profession. In the meantime, the review needs to incorporate a thorough consideration on work procedure such as the Plan of Work (RIBA, 2013) with regard to interconnections among identified cognitive domains; moreover it is always necessary to incorporate learning from the best practice in CM. At the initial stage of $\mathrm{CMBOK}$ development, as described here, a technical review into the two existing BOKs was conducted through a comprehensive comparison between them and this comparison study can help to develop the CMBOK framework at initial stage.

The sources of knowledge are critical for the establishment and justification of a dependable cognitive framework of professional knowledge. Two reference knowledge frameworks including CEBOK (ASCE, 2008, 2019) and PMBOK for construction management (PMI, 2016) are recommended for both the structure and contents development of CMBOK. Through the author's initial study on an outline structure of CMBOK, a preliminary framework of 18 cognitive domains under 3 management domains is put forward in Table 2. This preliminary main structure was developed in comparison with the two highly relevant cognitive frameworks, i.e., CEBOK and PMBOK for CM, respectively, and through evidence based learning from various sources, including:

- Standard industrial classifications such as the UK Standard Industrial Classification of Economic Activities (ONS, 2009),

- Databases run by both professional bodies, including the ASCE Civil Engineering Database and the ICE Virtual Library, 
TABLE 2 | Cognitive domains of professional BOK.

\begin{tabular}{lll}
\hline & \multicolumn{1}{c}{ Cognitive domains } \\
\hline CEBOK (ASCE, 2019) & PMBOK for CM (PMI, 2016) & Proposed preliminary main structure of CMBOK \\
\hline 1. Mathematics & 1. Project integration management & People/workforce \\
2. Natural sciences & 2. Scope management & 1. Enterprise management \\
3. Social sciences & 3. Schedule management & 2. Knowledge management \\
4. Humanities & 4. Cost management & 3. Stakeholder management \\
5. Materials science & 5. Quality management & 4. Workforce management \\
6. Engineering mechanics & 6. Resource management & Product/production \\
7. Experimental methods and data analysis & 7. Communications management & 5. Cost management \\
8. Critical thinking and problem solving & 8. Risk management & 6. Design management \\
9. Project management & 9. Procurement management & 7. Engineering management \\
10. Engineering economics & 10. Stakeholder management & 8. Facilities management \\
11. Risk and uncertainty & 11. Health, safety, security, and & 9. Plant management \\
12. Breadth in CE areas & & environmental management \\
13. Design & 12. Project financial management & 10. Quality management \\
14. Technical specialization & & 11. Resources management \\
15. Sustainability & & Processes \\
16. Communication & & 12. Communications manage \\
17. Teamwork and leadership & & 13. Supply network manage \\
18. Attitudes & & 14. Management systems \\
19. Lifelong learning & & 15. Procurement manage \\
20. Ethical responsibility & & 16. Risk management \\
21. Professional responsibilities & 17. Time management
\end{tabular}

and professional publishers, including Elsevier, Emerald, McGraw-Hill, Sage, Springer, Taylor \& Francis, and Wiley, etc.,

- Books published in construction management by worldrenowned scholars,

- Professional reports by top construction management organizations such as high-ranked main construction contractors (EMAP, 2017, 2018; ENR, 2018),

- Degree programmes accredited by professional bodies such as the American Council for Construction Education (ACCE, 2017), the Chartered Institute of Building (CIOB, 2018a), and the Royal Institution of Chartered Surveyors (RICS, 2018), and

- The author's extensive observations on site and online in relation to construction management for numerous projects worldwide.

The 18 cognitive domains proposed as the preliminary main structure of $\mathrm{CMBOK}$ (see Table 2) are divided into three categories in terms of management domains, including People/Workforce, Product/Production, and Processes, which are consistent with the three generic management domains identified through the author's extensive review on five main management theories (see Figure 1). The incorporation of the three management domains into structuring $\mathrm{CMBOK}$ here is based on the following considerations:

- CM practices are well-guided and supported by generic management theories,

- The development of CM theories is based on both management science and professional practices,

- The three management domains can provide an extensive coverage to $\mathrm{CMBOK}$ related issues in not only professional practices, but also education, training, research and development, and
- The need for and potentials of further research and development to sustain dependable CM services for the sustainable built environment.

Details about how the preliminary main structure of $\mathrm{CMBOK}$ (see Table 2) was defined under these four considerations are describe below in response to the three management domains.

For the management domain on People/Workforce in the case of construction management, four cognitive domains are proposed here for the CMBOK framework, and these include the management of Enterprises in relation to construction organizations, the management of Knowledge to support construction practices, the management of Stakeholders involved in various construction operations, and the management of Workforce to undertake construction activities at both project and non-project scale. The choice and definitions of People/Workforce related cognitive domains for CMBOK are essentials for developing its technical details relating to the constitution and competence of workforce working on either building or infrastructure project at various stages where construction management services are in need.

For the management domain on Product/Production in the case of construction management, seven cognitive domains are proposed here for the CMBOK framework, and these cover the management of construction project at various work stages across the whole life to cover the management of Cost across project life cycle; the management of Design upon interconnected technical outcomes across three stages covering concept design, developed design, and technical design; the management of Engineering solutions during construction, maintenance, repair, refurbishment, decommissioning and demolition; the management of Facilities 
in terms of relevant professional services at operation stage; the management of Plant at both construction and operation stage, the management of Quality of built assets in construction, maintenance, repair, refurbishment; the management of the use of Resources in relation to key considerations on quality, quantity, and embodied energy, etc. The choice and definitions of Product/Production related cognitive domains for $\mathrm{CMBOK}$ are essentials for developing its technical details relating to the physical products and production of buildings and infrastructures that construction management profession can support.

For the management domain of Processes in the case of construction management, seven cognitive domains are proposed for the $\mathrm{CMBOK}$ framework cover the management of Communications, the management of Supply network, the use of Management systems for various purposes on either individual issues such as environment, health, quality, safety, and welfare, or all tasks of the entire project; the management of Procurement through sound procedure and effective contract control; the management of Risk and Time at various work stages and scopes across project life cycle; and the management of Changes and Emergency whenever unexpected issues may occur in the whole project life. The choice and definitions of Processes related cognitive domains for $\mathrm{CMBOK}$ are essential for developing its technical details relating to a whole range of processes of making the built environment built through construction management services.

In addition to the main structure of CMBOK framework, there is another aspect constituting the entire challenge of developing CEBOK, for which the substructure of the main knowledge framework under the 18 cognitive domains described above needs to be defined. It is the author's consideration that the definition of the substructure system also relies on all knowledge sources identified for the proposed preliminary main structure of $\mathrm{CMBOK}$.

A further review into three key sources of information was conducted to detect whether the 18 cognitive domains proposed as the preliminary main structure of CMBOK could be recognized at a satisfactory level. Table 3 presents a comparison from this review, in support of three sets of key references selected from CIOB, British Standards Institution (BSI), and ISO, respectively.

The three sets of key references (see Table 3) selected for this comparison study include:

- CIOB (2014) Code of practice for project management for construction and development, in harness with several other related publications including the Design Manager's Handbook (Eynon, 2013), CIOB (2015) Time and Cost Management Contract suite, CIOB (2018b) report on Improving Quality in the Built Environment, CIOB (2018c) Guide to Good Practice in the Management of Time in Major Projects, and CIOB (2018d) course on Accident Investigation and Root Cause Analysis.

- BSI (2006) Guide to project management in the construction industry, and
- ISO (2017a) standards for construction, in harness with several other related ISO standards with regard to improving the performance of construction management services, for which relevant issues on quality, productivity, and sustainability, etc. (Bernold and AbouRizk, 2010) need to be dealt with.

It looks from this comparison study that all 18 cognitive domains proposed to structure the CMBOK are well-covered by three sets of key references in terms of various issues in construction management practice. This coverage indicates a good justification associated with the preliminary main structure of CMBOK proposed here. Therefore, the CMBOK framework proposed in Table 2 is recommended for further use to fulfill the gap on the shortage of such a BOK currently available for construction management at various scales in terms of practices, education and training, and research and development.

For CEBOB, in addition to its structure system, it is a continued process supported by professionals to add contents into this structured knowledge system. The contents of CEBOK under an established knowledge structure are gigantic in terms of the amount of knowledge accumulated from long-term practice and research in construction management across industry sectors worldwide. From this point of view, it is ideal to have an international organization to lead the development and maintenance of CMBOK, which can be widely recognized and used for construction management.

\section{INTELLIGENT CONSTRUCTION MANAGEMENT SYSTEM}

The second grand challenge to discuss is the establishment and utilization of intelligence pervasive construction management systems to thoroughly support project-based practices at workplaces across work stages. From the author's point of view, an intelligence pervasive management system is a computer aided management system that incorporates the use of experts' knowledge and artificial intelligence (AI) based on the collection and process of relevant data and information from the real world. With regard to the importance of Industry 4.0, the construction industry is now under rapid transformations to adopt digital technologies that enable innovations in products and processes across the supply chain network, and it has become inevitable to incorporate new concepts driven by digital technologies into traditional management systems such as management information system (MIS) and enterprise management system (EMS) for construction management.

It has been always an inspiring learning experience for the author to look into progresses on research and development in the theory and solutions of AI since he put forward the concept of intelligent methods for construction engineering and management (Chen and Xu, 1996; Xu and Chen, 1997). In connection with the fast development of information and communication technologies (ICT) since 1990s, recent research and development in applied AI solutions for enhanced practice in construction management has shown insightful perspectives and effective progressions. For example: 
TABLE 3 | Recognition of cognitive domains proposed for CMBOK.

Cognitive domains of CMBOK
Key topics adopted in selected references

BSI (2006) Guide to project management in the construction industry
Code of practice for and development
ISO (2017a) standards for construction

\section{PEOPLE/WORKFORCE}

1. Enterprise

Project governance

Project organization structure

Legislation; benchmarking

Identification of issues; project life cycle

2. Knowledge

Stakeholder identification and management

3. Stakeholder

Project team duties and responsibilities; performance management plan and monitoring

4. Workforce

PRODUCT/PRODUCTION

5. Cost

Life-cycle costing; cost planning and controls; time and cost management contract suite (CIOB, 2015)

6. Design

Managing the design delivery; technical design and production information; design manage (Eynon, 2013)

7. Engineering

Feasibility studies; value engineering

Stakeholder requirements and constraints

Diversity of disciplines involved; personnel-related processes workforce manage (ISO, 2018k)

Collaborative business relationship manage (ISO, 2017c)

Knowledge libraries (ISO, 2013); knowledge management (ISO, 2018k)

Railway applications (ISO, 2018n)

Human resource management and workforce manage (ISO, 2018k)

Life-cycle costing (ISO, 2017b)

Cost management

Life-cyclecosting (1SO, $2017 \mathrm{~b})$

Configuration management; detailed design; design principles and materials standards

Feasibility evaluation

BIM (ISO, 2018a) and design life (ISO, 2018c)

Accessibility and usability (ISO, 2011); SUSTAINABILITY (ISO, 2018d); fire safety (ISO, 2018i)

Facilities management (ISO, 2018e); energy management and energy savings (ISO, 20180)

maintenance; the maintenance, repair, refurbishment, decommissioning and demolition of existing facilities strategy/considerations; operation and maintenance manuals

Plant maintenance facilities

Machinery and equipment (ISO, 2018j)

Quality management

Quality management (ISO, 2015a)

10. Quality

Site establishment

11. Resources

Quality management (CIOB, 2018b)

PROCESSES

12. Communications

Site waste management

Resource management

ICT; BIM; communications and procedures; strategic collaborative arrangements and working

13. Supply network

Procuring the supply chain and management

14. Management systems Project management systems; management systems for environment, health, safety and welfare, and quality

15. Procurement Procurement strategy; e-Procurement

16. Risk

Risk identification, assessment, and management

17. Time Project planning; time management (CIOB, 2018c)

18. Changes and emergency

\section{Communication-related processes}

Mobilization

Integrated management plan; project management system

Procurement-related processes

Risk-related processes

Work breakdown structure; scheme design; time-related processes

Changes management; changes control processes; changes in resource plans; schedule changes
Environmental management (ISO, 2018m)

Project information management (ISO, 2008); information and documentation (ISO, 2018I)

Business and supply chain continuity (ISO 2015b)

information management using BIM (ISO, 2018a); management system standards (ISO, 2018f)

Sustainable procurement (ISO, 2017d); construction procurement (ISO, 2018b) Risk management (ISO, 2018g)

Project, programme and portfolio management (ISO, 2018p)

Evacuation (ISO, 2009a,b); emergency management (ISO, 2018h)
Change management; emergency work (ClOB, 2015); accident investigation (ClOB, 2018d)
- The use of artificial neural network (ANN) (Waziri et al., 2017) across various predication related issues in construction management,

- The use of knowledge sustained analytic network process (ANP) (Chen, 2007) to evaluate options for informed decision making in construction management, and
- The integration with automation technology to deploy single-task and multi-task robots (Skibniewski, 1988; CastroLacouture et al., 2007; Bock and Linner, 2016; Black and Pettitt, 2018) in construction projects.

It has been further emphasized by Blanco et al. (2018) recently regarding the adoption of applied AI in construction 
management in terms of project planning optimization, constructability justification, materials and inventory management, and risk and safety management; and these applications all demand a systems-based approach (Briesemeister, 2018) to improve the quality and productivity of construction management. It looks that an integrative use of data, information and knowledge (DIK) (Allee, 1997; Walker, 2016) is now just in front of the construction management profession, while the DIK set can be collected from either construction projects or construction professionals in dealing with specific issues such as those listed in Table 2 in a more accurate and efficient manner.

In response to the increasing need for comprehensive use for DIK in construction management, a new concept about intelligent construction management system (iCMS) is described below in terms of its concept, purpose and value, conceptual model, and two tier systems. Hopefully this description could be useful for further considerations, discussions, and research and development in this area.

\section{Concept}

An iCMS is a construction management system aided by AI techniques that can trigger human/rational learning, thinking and acting (Russell and Norvig, 2010) in connection to integrated DIK clusters and their elemental sets (see Table 4), which are specifically structured on a spectrum of expected helpfulness to assist the use of human intelligence at an enhanced consistent level in CM practice.

The entire DIK set need to be carefully collected with continuous updating manually and/or automatically from various sources under the CMBOK framework, and this ensures the system performs effective practical support connecting with experts' wisdom, which can be derived from computing processes at different scopes covering project/programme level, enterprise/group level, and local/regional level, etc. in a high efficient manner toward excellent professional performance. The iCMS needs to be well-connected with DIK sources covering the management team and a range of databases and knowledge bases to ensure dependable support to construction management practice.

\section{Purpose and Value}

The purpose of incorporating an iCMS in practice is to equip the project-oriented management team with dependable technical toolkits for better CM service delivery. The iCMS toolkit aims to facilitate the integrative use of not only expertise and knowledge accumulated from the past practice, but also

TABLE 4 | DIK clusters and their elemental sets for CM.

\begin{tabular}{|c|c|c|c|}
\hline \multirow[b]{2}{*}{ Elemental set } & \multicolumn{3}{|c|}{ DIK cluster } \\
\hline & Data & Information & Knowledge \\
\hline People/workforce & \multicolumn{3}{|c|}{ CMBOK Cognitive Domain 01 to 04} \\
\hline Product/production & \multicolumn{3}{|c|}{ CMBOK Cognitive Domain 05 to 11} \\
\hline Processes & \multicolumn{3}{|c|}{ CMBOK Cognitive Domain 12 to 18} \\
\hline
\end{tabular}

data and information collected from the on-going project in real time. From the best practice point of view, specific DIK sets are required to deal with critical problems relating to the management of people/workforce, product/production, and processes across project stages.

The value of iCMS for construction management practice is its function to precisely perform calculated decision making support through the effective and efficient use of DIK. This calculation can be made through co-computing processes over a gigantic body of chaotic interactions among workforce, production, and processes within the dynamic project environment across work stages. Therefore, the iCMS is to provide a systematic approach to better using DIK that quantify chaotic interactions in construction projects. In terms of the need for continuous excellent performance across construction management teams, the iCMS is to run through computing systems as an essential smart assistant.

\section{Conceptual Model}

A conceptual model of iCMS is illustrated in Figure 2. The intelligence expected from such a system for construction management can be achieved in its capacity on the integrative use of relevant DIK through a formal work procedure based on individual management systems such as environmental management system (Chen and Li, 2006), health and safety management system (Griffith, 2010), knowledge management system (Anumba et al., 2005), quality management system (Thorpe and Sumner, 2004; Rumane, 2018), and project management system (Chen, 2018), etc., which can be dynamically connected inside individual project-oriented computer systems in connections with building information models (BIM) for continued accurate inputs and useful outcomes.

This conceptual model illustrated in Figure 2 consists of four functional entities that are connected through DIK and/or

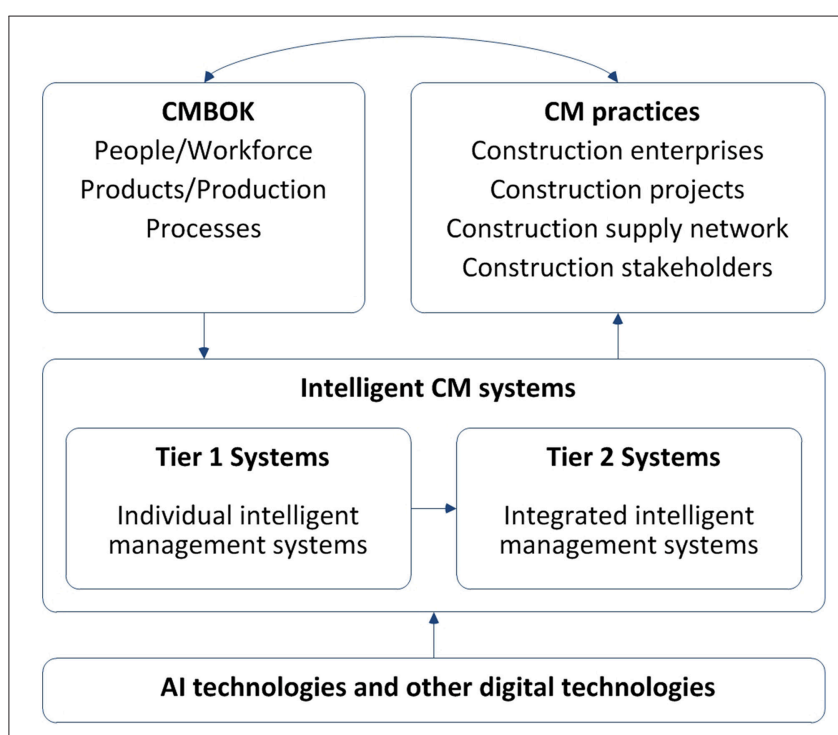

FIGURE 2 | A conceptual model of iCMS. 
supporting procedures, and these entities include $\mathrm{CMBOK}, \mathrm{CM}$ practices, intelligent $\mathrm{CM}$ systems, and $\mathrm{AI}$ technologies and other digital technologies.

A two-way connection between entity $\mathrm{CMBOK}$ and entity $\mathrm{CM}$ Practices is set up to describe their relationship, which covers the two aspects, including:

- $\mathrm{CMBOK}$ as a collection of well-structured professional knowledge is to accumulate relevant DIK from CM practices, and the inputs under a given $\mathrm{CMBOK}$ structure are collected from $\mathrm{CM}$ practices, which covers all individual practices on construction management; and

- CMBOK would influence/support CM practices at various scales through purpose driven application/reuse and/or continuous learning/training based on its classified collections.

For the entity of intelligent CM systems, it has two sub-entities forming an entire tier system, which is described in the next section. This entity is integrated with three other entities in the following ways:

- $\mathrm{CMBOK}$ provides the structure and contents of DIK for individual intelligent CM systems,

- CM Practices can be assisted/supported through the use of individual intelligent CM systems, and

- AI technologies and other digital technologies are adopted to support individual intelligent CM systems with expected functions.

It is anticipated that this conceptual model can be useful to clarify the concept of iCMS and its research and development toward intelligent construction management.

\section{Tier Systems}

Exploratory research facing grand challenge on intelligence systems for construction management can be conducted through two stages, including the initial stage on sub-systems, i.e., individual management systems, and the secondary stage on an entire iCMS system, i.e., an integration of all its elemental subsystems. They are called Tier 1 systems and Tier 2 systems, respectively, here based on different functions that individual systems can provide. Generally speaking, Tier 1 systems are subsets of Tier 2 systems. The research and development of the two types of systems highly rely on thorough system analysis and design, reliable inputs, and effective use of DIK within the system to support usages in construction management upon various issues and situations. A brief description about the two types of systems is given below for discussion toward further actions in research and development.

Tier 1 systems: Individual intelligent management systems. These systems are designed, developed and implemented for construction management in specific areas as listed in Table 2. For example, the system for purposes on managing people/workforce, product/production, and processes, respectively, could be:

- An intelligent EMS for managing people/workforce involved in construction projects or project enterprise at various levels in an organization of either clients' or contractors',
- An intelligent cost/quality management system for managing product/production targeted by either an organization of clients' through the investment into their capital projects, or an organization of contractors' through the delivery of entrusted construction projects, and

- An intelligent information and communication management system for managing processes deployed within an organizational environment of construction projects on either clients' or contractors' side.

The intelligent functionality and capability of these individual management systems need to be casted by incorporating a number of interconnected inputs on DIK under the CMBOK framework. There have been initiatives in research and development in Tier 1 systems. For example, Grahovac and Devedzic (2010) presented an expert system to support decision making in cost management; although it was not for construction cost management, their experiment has indicated a promising application of intelligent cost management system in construction, and such an application can be hybrid by incorporating the use of other relevant techniques such as the research that Chou et al. (2015) have conducted by interactively using Genetic Algorithm (GA), ANN, and Case-based Reasoning (CBR) to predict project award price, and this hybrid use of intelligent methods can be further integrated with BIM (Allplan, 2018) for intelligent cost management at various project stages. By learning lessons from other sectors, such as the healthcare sector where it was found that an intelligent cost management system, for example, can leverage relevant data to swiftly identify opportunities so as to achieve savings of $\$ 10$ per member per month (PMPM) with a conservative calculation (MedSolutions, 2013), it can be anticipated with a positive sensation that the adoption of individual intelligent management systems in construction can significantly improve construction management on various aspects.

According to the concept of iCMS, the use of well-developed practical solutions of AI is essential for Tier 1 systems. In addition to the example given above, it is obvious through literature review that initiatives in research and development in Tier 1 systems have widely developed through the use of AI techniques in natural language processing, knowledge representation, automated reasoning, machine learning, computer vision, and robotics (Russell and Norvig, 2010) for construction management. The following are good examples for Tier 1 systems:

- A natural language processing system to extract precursors and outcomes from unstructured injury reports (Tixier et al., 2016),

- A knowledge extraction and representation system for narrative analysis in the construction industry (Yeung et al., 2014),

- An expert system for crack diagnosis in cast-in-place reinforced concrete structures (Chen et al., 1999),

- A construction noise prediction model based on case-based reasoning in the preconstruction phase (Kwon et al., 2017),

- A machine-learning model for estimating construction costs (Rafiei and Adeli, 2018), 
- A computer vision-based workforce activity assessment in construction (Luo et al., 2018),

- A robotic approach to construction waste recycling (Wang et al., 2019).

The adoptions of individual AI techniques in these exploratory research and development have demonstrated the effectiveness of Tier 1 systems to support construction management, and these systems also shows potentials for integration to form a more powerful iCMS toward Tier 2 systems.

Tier 2 systems: Integrated intelligent management system. In principle, an integration of several individual Tier 1 systems can be further developed by using groupware (collaborative software) technology to form collaboration systems (Nunamaker et al., 2014), and this integration is expected to enable more functional intelligent construction management system. From a conceptual point of view, the integration of selected Tier 1 systems can yield one Tier 2 system that can support construction management activities in a transdisciplinary way in multiple functional areas covered by Tier 1 systems, respectively. There are different levels of system integrations, for example, it can be either an integration of several individual Tier 1 systems for project-specific intelligent management based on individual contracts with clients, or the integration of all individual types of Tier 1 systems to form all-round intelligent management for general use by main contractors. In other words, for a bespoke iCMS, the scope of system integration may reflect the scope of construction management contract for which the system is expected to work for in specific projects. On the other hand, there is another type of Tier 2 systems, for example, the i-Construction system (STI, 2017b), which is developed as an entire system with sub-systems to perform designed functions for generic use to support CM activities across all types of projects. In comparison with groupware integration that satisfy specific needs for construction management at suitable workplaces in the project environment, the new development of an entire intelligent system faces more challenges in terms of the incorporation of complex sub-systems and human intelligence with thorough connections to CMBOK and DIK in a general way to make enable all necessary functions for construction management.

There are specific issues to be dealt with in the research and development for iCMS. For example, it is essential to not only sufficiently describe DIK and sources for collection, but also accurately collect and effectively use them in order to make the system useful. By learning lessons from construction management practice in relation to the use of computer systems such as a BIM system, for which a comprehensive collection of relevant data and information from construction stage may not be typically well-functioned inside the system and consequently leave data gaps less filled across design, construction and operation stage. Therefore, a set of essential questions and answers under systematic considerations connecting to multiple disciplines within construction projects may help system design, development and usage.

\section{DIGITAL INNOVATIONS}

The third grand challenge to discuss is the digital innovation throughout its project-oriented work procedure. The need for and demand on innovative reengineering (Love and $\mathrm{Li}$, 1998) in construction management has progressively emerged and increased through the requirement and provision of dependable management services in the construction sector. In the meantime, the availability of advanced technical solutions in sciences and technologies has greatly supported (with huge potentials) the technical enhancement of construction management by incorporating interdisciplinary digital innovations. The discussion here focuses on adopting advanced technologies in relation to the theories and solutions of informatics and automation for further development in construction management.

\section{Construction Informatics}

Construction informatics is the interdisciplinary science of the application of advanced computing and ICT to construction engineering and management. The adoption of technical solutions based on ICT driven research and development has been significantly increasing in construction management over the past several decades. For example, technologies such as artificial intelligence (AI), artificial reality (AR), which is the author's term to cover virtual reality (VR), augmented reality (AR), mixed reality (MR), BIM; geographic information systems (GIS), global positioning system (GPS), management information system (MIS), and process simulation (PS) etc. have all been applied in research and development for practice enhancement in management on people/workforce, products/production and processes in building and infrastructure projects. Table 5 makes a summary of exemplar research and development initiatives focused on adopting various digital innovations for construction management through research and development. These initiatives were identified from not only relevant strategies and practices by top international construction contractors, including Balfour Beatty, Bechtel, Kajima, Laing O’Rourke, and Skanska, but also some representative academic research published in China, European Union, UK, and USA.

These technical innovations have demonstrated anticipated results such as significantly improved work efficiency via multidisciplinary construction information management although there are still potentials for further research and development in terms of system functionality and interoperability. On the other hand, it is also necessary for interdisciplinary digital innovation to incorporate useful ideas from various professions relating to project management. For example, it is an unresolved question regarding how the incorporation of economics, psychology and sociology (Harty, 2005; Winch, 2009; Mascia, 2012; Walker, 2015) focusing on the performance of individuals and project team into ICT systems for construction management can make further technical enhancement. Further interdisciplinary digital 
TABLE 5 | Exemplar R\&D initiatives on construction informatics.

\begin{tabular}{|c|c|}
\hline TECH & Digital innovations through research \& development (R\&D) \\
\hline Al & $\begin{array}{l}\text { - Intelligent methods for construction engineering and management (Xu and Chen, 1997) } \\
\text { - Managing networks in project-based organizations (Pryke, 2017) } \\
\text { - Evidence-based learning for safety management (Chen et al., 2017) } \\
\text { - Effective lesson learning for construction project management (Fischer et al., 2018) } \\
\text { - Experts perspectives on Al enabling machine learning in construction (Smith, 2018) } \\
\text { - Using systems and Al in work-style reform (Kajima, 2018) } \\
\text { - Digital strategies on digital activities including machine learning and data analytics (Skanska, 2018) } \\
\text { - Innovating the construction site through big data and analytics (Bechtel, 2018) }\end{array}$ \\
\hline AR & $\begin{array}{l}\text { - Innovation strategy on the digital future of the infrastructure industry (Balfour Beatty, 2017) } \\
\text { - MR for automated solutions for construction progress monitoring (CSIC, 2017) } \\
\text { - The use of VR in the built environment (Whyte and Nikolić, 2018) } \\
\text { - Immersive technologies powering a revolution in customer experience (NBS Research, 2018) } \\
\text { - Digital strategies on digital activities within immersive environments (Skanska, 2018) } \\
\text { - Innovating the construction site through augmented and virtual reality (Bechtel, 2018) }\end{array}$ \\
\hline GIS/GPS & $\begin{array}{l}\text { - GIS solutions for community development, civil engineering and surveying (ESRI, 2002, 2007, 2008) } \\
\text { - Integration with GIS for resources efficiency (Li et al., 2005) } \\
\text { - Emerging technologies for construction delivery (NASEM, 2007) } \\
\text { - Using digitalized subsurface information (Campbell, 2017) } \\
\text { - Underground asset mapping in the UK (Future Cities Catapult, 2017) }\end{array}$ \\
\hline MIS & $\begin{array}{l}\text { - Enterprise resource planning (ERP) and Customer relationship management (CRM) (Microsoft, 2016) } \\
\text { - Deploying construction information model/modeling (CIM), a site management system linked with automated construction (Kajima, 2018) } \\
\text { - Adopting Total Management System for building construction (Kajima, 2018) } \\
\text { - Implementation of ERP systems (Skanska, 2018) } \\
\text { - Initiative on Digital Enterprise Program, including a Digital Supply Chain System, to tie in tools, work processes and procedures (Bechtel, 2018) }\end{array}$ \\
\hline
\end{tabular}

innovations through the use of theory and techniques in construction informatics may therefore need to consider both tangible and intangible aspects within project environment and related scenarios.

From a research and development point of view, there are a number of areas in interdisciplinary digital innovation for enhanced practice and learning in construction management, and these areas can be connected to the three identified domains (see Figure 1) of construction management with regard to innovations in:

- People/Workforce management. For example, DIK collection, analysis, and integrative usage,

- Product/Production management. For example, Performance (on Cost, Quality, and Schedule, etc.) modeling, monitoring and assessment, and

- Processes management. For example, Process (for Construction Engineering and Management) reengineering design and coordinated implementation.
In the area of applied AI with regard to the need for alternative research approaches (AlSehaimi et al., 2013) as well as the provision of useful technical solutions, the deep learning technology has indicated a promising future for adoption in order to improve the productivity of construction management professionals, and the technical enhancement needs to be pursued toward accuracies in management in terms of interconnected working efficiency within networked teams to effectively tackle persistent problems relating to major issues on cost, quality and time in project delivery.

\section{Construction Automation}

Construction automation is regarded as the use of automatic equipment or machines in construction. The automation technology has been increasingly studied and adopted in the construction sector (Bock, 2015; Chen et al., 2018a; Hawksworth et al., 2018) to improve not only the quality of products but also the efficiency of processes as well as resources use. 
For construction management, new industrialized construction engineering solutions have been introduced to practices, and these include:

- Design for Manufacturing and Assembly (DfMA) (BCA, 2016),

- Design for deconstruction/disassembly (Rios et al., 2015),

- Digital production systems such as 3D printing (Bechtel, 2018; De Laubier et al., 2018; García de Soto et al., 2018; Skanska, 2018),

- Digital data collection and construction verification systems such as drones (Skanska, 2018), and 3D scanning (Faro, 2019),

- Autonomous construction equipment (Black and Pettitt, 2018) and vehicles (Bechtel, 2018), and

- Construction site automation (Kajima, 2018).

These industry led initiatives have shown progressive achievements and new opportunities for lean construction (Alarcón, 1997) toward a wide range of technical enhancements at interdisciplinary scale that integrates construction engineering and construction management across the supply network. For both research and practice to be well-prepared for this disruptive innovation in the construction sector, it is important to learn lessons from the manufacture industry where the automation technology and industrialized automation systems have been very well-developed and widely used in a process of continuous innovations over the past many decades, and this can significantly change the landscape of construction management in terms of professional competence and resources efficiency oriented performance toward the best practice. The adoption of automatic systems in construction projects brings the opportunity for professionals to reconstruct (Morris, 2013) management procedure and associated activities and systems.

For interdisciplinary digital innovation in construction management, it has been learnt from past research and development that both decent deep learning from and efficient DIK sharing in multiple disciplinary areas are necessary and beneficial for a dedicated construction management team; in addition, a fast paced innovation process driven by wellorganized collaboration under the Blue Ocean strategy (Kim and Mauborgne, 2004) can be achieved through team-based multi-disciplinary learning, which can foster as well as enable powerful integrations of new digital DIK compounds into existing construction management. For example, the Asta Powerproject (Elecosoft, 2018), which was originally developed for construction planners to develop and maintain project schedules by using the critical path method (CPM) like other same type of software packages for managing construction schedule, has now evolved to be a powerful 4D planning solution by linking project plans made by construction planners to $3 \mathrm{D}$ models provided by design engineers so as to match the need for adopting BIM in construction management. The multidisciplinary connection realized in this software package has demonstrated the advantage of further research and development in leading the way forwards. A continuous leadership in research and development is therefore inevitable by providing new solutions on not only Construction Informatics but also Construction Automation, and those innovative digital solution can satisfy new needs for digitalization across various interconnected disciplines within the construction project environment to serve more (wider and deeper) in required management services.

\section{MEGAPROJECT DELIVERY}

The fourth grand challenge to discuss is the delivery of megaproject with regard to satisfactory performance toward targets on life-cycle cost, quality of the built environment, resources use, and staged schedule, etc. A megaproject is a large-scale capital project typically costing more than US \$1 billion (PricewaterhouseCoopers, 2014), and it can be considered as a subset of major projects which have a wide scope of project costing above US100m for example. Megaproject has its uniqueness in terms of their significant and substantial impacts on social, technical, economic, environmental and political (STEEP) spheres. Generally speaking, these impacts are related to the big set of designed functions and service capacities under the purpose to transform public services and to deliver a robust infrastructure system to serve people and/or the nature in both short and longer term. There have been a huge amount of lessons learnt from past practices on megaproject development and operation across the world. One of the significant and persistent problems in megaproject delivery is the overruns on cost and time against estimated budget and schedule, and this has been widely recognized as specific megaproject risks (Flyvbjerg et al., 2003) and the need for mature risk management (Jia et al., 2013). It is therefore a grand challenge for further research and development to explore better technical solutions that are capable to support significant performance improvement on construction management in megaproject delivery. From this point of view, the description here about the grand challenge in megaproject delivery focuses on two relevant issues, including megaproject knowledge, and knowledge-driven solutions.

\section{Megaproject Knowledge}

It is evident through the author's extensive literature review and observations from both research and practices that a new research frontier in megaproject management with regard to scope, contents and potentials in relation to challenges, methodologies and solutions has emerged from a series of initiatives in focused research and practices. Table 6 is used to summarize the author's literature review in relation to megaproject knowledge, and it covers a range of topics about the performance of megaproject delivery. According to this summary, publications from research and practices around the world, especially from world's top economies, have accumulated a quick increase of megaproject knowledge in the past decade, and can strongly foster and support further research and development being embarked on this new frontier for research into megaproject delivery. As summarized in Table 6, accumulated knowledge for megaproject delivery can be classified in the 
TABLE 6 | Classified publications on megaproject delivery.

\section{Publications \\ BOOKS ON MEGAPROJECT SUSTAINABILITY (Chen and Whitehead, 2015)}

\begin{tabular}{ll}
\cline { 2 - 3 } & Authors' location
\end{tabular}

Authors' location Year

Social issue: Urban megaprojects (Santamaría, 2013)

Technical issue: Engineering impacts of megaprojects (Brunn, 2011)

Economic issue: Socioeconomic evaluation of megaprojects (Lehtonen et al., 2017)

Ecological issue: Environmental management in megaprojects (Yang, 2017)

Political issue: Myth and political reality of megaprojects (Gil et al., 2017)

BOOKS ON METHODOLOGICAL ISSUES RELATING TO SUCCESSFUL MEGAPROJECT DELIVERY

\section{Decision making}

Cost-benefit analysis, planning and innovation (Priemus et al., 2008)

Concepts, strategies, and practices for success in megaprojects (Merrow, 2011)

Decision making on transportation infrastructure investment (Berechman, 2018)

Project finance

Infrastructure project finance and project bonds in Europe (Rossi and Stepic, 2015)

Project governance

The Governance of energy megaprojects (Sovacool and Cooper, 2013)

The governance of infrastructure megaprojects (Wegrich et al., 2017)

UK

USA

France

China

UK and USA

Project leadership

Leading complex projects (Merrow and Nandurdikar, 2018)

Delivering successful megaprojects (Kwegyir-Afful, 2018)

$\begin{array}{ll}\text { EU } & 2018 \\ \text { USA } & 2011 \\ \text { USA } & 2018\end{array}$

\section{Multi-stakeholder lessons learned}

Case study on the Three Gorges project (Luk and Whitney, 1993)

Advice from professionals in managing gigaprojects (Galloway et al., 2012)

Lessons learnt from a trans-Andean megaproject on biodiversity (Alonso et al., 2013)

Lessons on risk and management from the Big Dig project (Greiman, 2013)

What government can learn from London 2012 (Norris et al., 2013)

Politics on the Tappan Zee project (Plotch, 2015)

The history and politics relating to the LAPSSET project (Browne, 2015)

Case study on the San Francisco-Oakland Bay Bridge project (Frick, 2016)

Lessons learnt from large infrastructure projects in Germany (Kostka and Fiedler, 2016)

\section{Project procurement}

Procuring successful megaprojects (Hart, 2015)

\section{Management solutions}

Megaproject risk analysis and simulation (Boateng et al., 2017)

\section{Management theories}

Megaprojects challenges and recommended practices (Hatem and Corkum, 2010)

Megaproject management (Ren, 2012)

Handbook on megaprojects (Priemus and van Wee, 2013)

Handbook of megaproject management (Flyvbjerg, 2017)

Major infrastructure projects planning for delivery (Ochieng et al., 2017)

Fundamental theories of infrastructure construction management (Sheng, 2018)

THEMED COLLECTIONS IN 12 INTERNATIONAL JOURNALS

Complexities in megaproject management (Li and Guo, 2011)

Megaproject management: The state of the art (Hagan et al., 2012)

Planning and managing sustainable infrastructural projects (Brookes et al., 2012, 2014)

Planning and managing infrastructure megaprojects (Pells, 2014)

Global similarities and differences on megaprojects (Brookes and Zhang, 2014)

Classics in megaproject management (Flyvbjerg, 2015; Flyvbjerg and Turner, 2018)

Megaproject sustainability (Chen and Whitehead, 2015)

Megaproject management (Chen et al., 2016, 2018b), etc.
EU

2015

USA

2013

Germany

2017

USA

2018

UK

2018

Canada

1993

USA

2012

USA

2013

USA

2013

UK

2013

USA

2015

UK

2015

USA

2016

Germany

2016

$\mathrm{AU}$ and $\mathrm{UK}$

2015

UK

2017

USA

2010

China

2012

Netherlands

2013

$A \cup, E U, U K$, and USA, etc.

2017

UK

2017

China

2018

$\begin{array}{ll}\text { China } & 2011 \\ \text { EU and UK } & 2012 \\ \text { EU and UK } & 2012 \\ \text { USA } & 2014 \\ \text { UK and China } & 2014 \\ \text { EU and UK } & 2018 \\ \text { UK } & 2015 \\ \text { UK } & 2016\end{array}$


TABLE 6 | Continued

Publications

Scop

Authors' location Year

Organizational theory perspective of megaprojects (Söderlund et al., 2016)

Organizational behavior and governance of megaprojects (Li et al., 2016)

Social responsibilities for megaproject management (Shen et al., 2017)

$\mathrm{AU}$ and $\mathrm{EU}$

Supply chain management in megaprojects (Wang et al., 2017)

Contracting and megaprojects (Locatelli et al., 2017)

Infrastructure mega-project management (Guo and Sheng, 2017)

Environment and society oriented studies on megaprojects (Fadaee and Schindler, 2017)

Complexity of infrastructure megaprojects (Wu et al., 2018)

Mega engineering projects in challenging geological environments (Dong et al., 2018)

PRACTITIONERS' LEARNING LEGACY ON MEGAPROJECT DELIVERY

Holyrood project (Scottish Parliament, 2005)

London 2012 Olympic and Paralympic Games (ODA, 2011, 2015)

China 2016

China

2017

Crossrail Learning Legacy (Crossrail, 2018)

AU and USA

EU and UK 2017

China 2017

Edinburgh Tram Network project (ETI, 2018)

UK 2017

China 2018

China, UK, Italy 2018

$\begin{array}{ll}\text { UK } & 2005 \\ \text { UK } & 2011 \\ \text { UK } & 2018 \\ \text { UK } & 2018\end{array}$

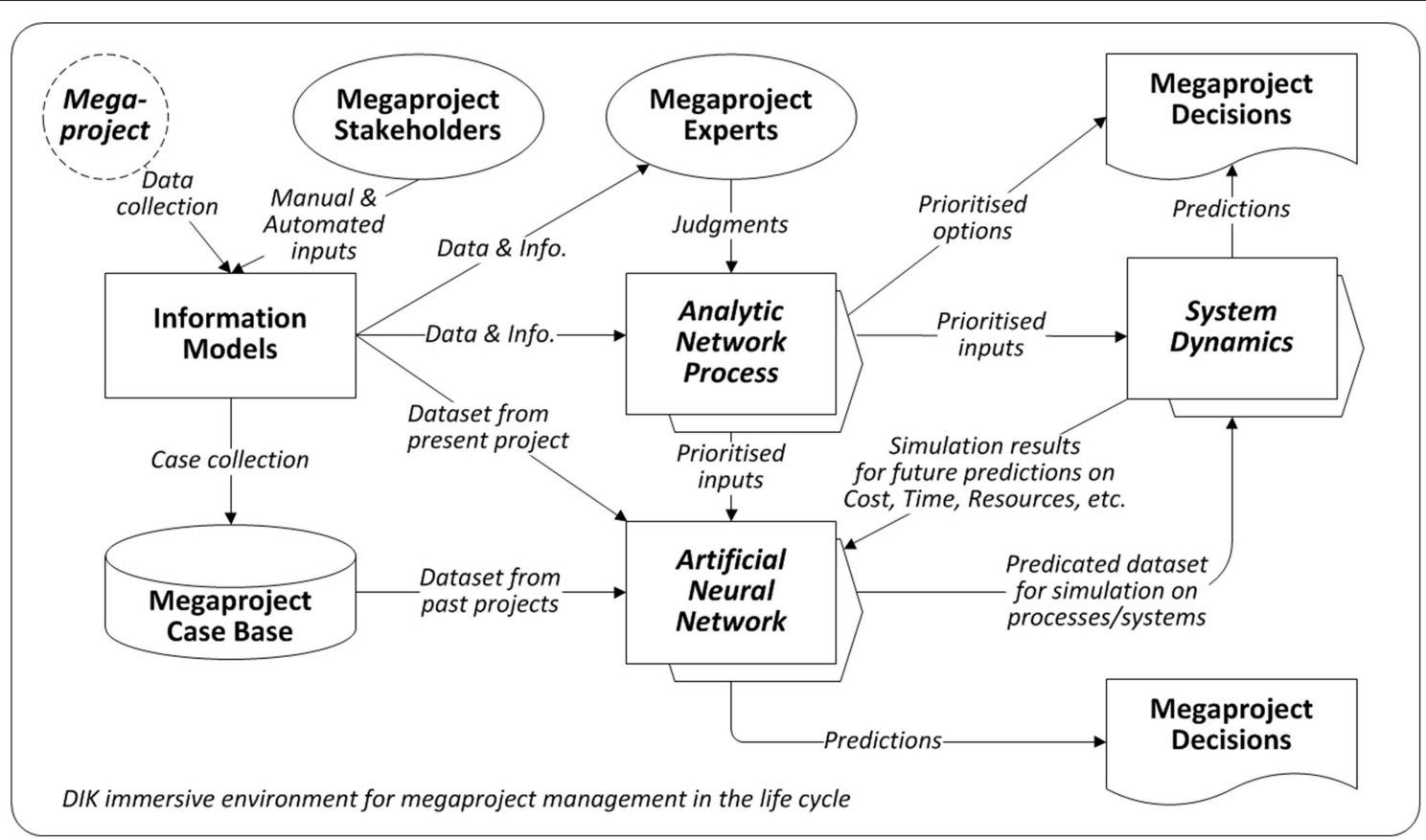

FIGURE 3 | Knowledge-driven solutions for megaproject management.

following four categories of publications to form a new landscape of dedicated research:

- Books on various issues relating to megaproject sustainability with regard to STEEP issues;

- Books on methodological issues about successful megaproject delivery in relation to Decision making, Project finance, Project governance, Project leadership, Multi-stakeholder lessons learned, Project procurement, Management solutions, and Management theories;
- Themed collection of research articles in 12 international journals; and

- Practitioners' learning legacy on megaproject delivery.

The purpose of Table 6 is to develop a knowledge structure in terms of important issues relevant to performance improvement in megaproject delivery. Knowledge materials that were used to establish this structure include books, themed issues of journals, and practitioners' learning legacy. With regard to other types of relevant publications such as numerous individual 
articles published in journals and newspapers, in addition to case oriented study, a further review and collection can be conducted to verify and improve this structure, to enrich the collection of knowledge materials, and to incorporate megaproject knowledge into $\mathrm{CMBOK}$. As it is always important to use DIK in both effective and efficient way in construction management practice, one challenge in front of further research and development is inevitably to focus on knowledge-driven solutions, which are expected to provide well-informed decision making support in areas relating to construction management. For megaproject, due to the scale and complexity of management, the value and power of structured knowledge reuse are expected and in need for proofs from future practices.

\section{Knowledge-Driven Solutions}

Knowledge-driven solutions refer to techniques and tools that can facilitate an effective and efficient use of knowledge in dealing with questions or problems in management practices. For megaproject delivery, it is assumed that one possible solution to effectively tackle the problem on overruns within an enlarged project scale, which is probably beyond the one where traditional theories, techniques and processes can work well for small-size projects, is to deploy significant technical enhancement through the development and enablement of reengineering-led leadership and capability on various aspects of construction management. In addition to the adoption of digitalized tools to increase productivity at work stages, knowledge-driven solutions that can facilitate a thorough use of DIK in construction management are reckoned to improve the quality of professional services and expected outcomes with regard to contract, legislation, and professional code, etc.; and to increase the momentum that the use of DIK can add into the culture and impacts of construction management enterprises.

Figure 3 is used here as an example to illustrate how knowledge-driven solutions can be crafted for decision making support in a DIK immersive environment of megaproject management. It aims to establish possible connections among five solutions, including:

- Information models such as BIM and CIM to accumulate DIK from stakeholders and site of the megaproject,

- Megaproject case base to store DIK from current and past megaprojects,

- Analytic network process to reuse DIK to identify priorities among project related options,

- Artificial neural network to reuse DIK to derive conclusions for individual project related goals, and

- System dynamics to reuse DIK to predicate possibilities upon specific project related issues.

This figure also provides indications about all connections across exemplary solutions to clarify how stakeholders and experts can work together within DIK immersive project environment where various ways of using knowledge are made available and integrated toward better-performed services in construction management.
An example of research into the use of knowledge-driven solutions to deal with the big issue on cost and time overruns in megaproject delivery is the experimental case studies conducted by Boateng et al. (2017) who explored the integrative use of ANP (Saaty, 1996) and system dynamics (SD) (Sterman, 1992) to predict cost and time overruns in the Edinburgh Tram Network project, which has a total capital cost of approximately $£ 776$ million (Cardownie, 2017). The outcome from their experiment provided a promising accuracy above $80 \%$ in prediction on cost and time overruns, and the simulation method can be interactively used in project management to achieve optimized delivery processes across stages by timely adjusting errors that may cause problems. While it is necessary to reinforce structural and governance arrangements (Croft et al., 2016) in megaproject delivery, this research initiative and outcome is making a suggestion on the necessity to incorporate disruptive technical solutions in megaproject delivery, and has attracted practitioners' interest. As described by Davies et al. (2009), innovation through process-oriented systems integration by incorporating lean thinking (Womack and Jones, 1996) can significantly improve the performance of megaproject delivery. It is therefore anticipated that disruptive innovations such as the knowledge-driven systems through introducing the usages of new theories and technologies into megaproject management can effectively tackle the persistent problem such as the overruns on budget and schedule, and there is an array of value proposition canvases (Osterwalder et al., 2014) for reconstructing project management (Morris, 2013) toward proactive results through further practice-oriented exploratory research.

Regarding the challenge on megaproject delivery, as it is defined in this article as the one for best practices for which methods described under, the first three challenges need to be used in an integrative way.

\section{CONCLUSIONS}

This article provides brief discussions on four grand challenges connecting to further research and development in the subject field of construction management with regard to three technical domains on people/workforce, products/production and processes, respectively. In addition to an extensive review into current national/regional strategies for the construction sector in major economies, the four grand challenges were identified through the author's observations on academic research and professional practices in relation to the body of professional knowledge, intelligent management systems, interdisciplinary digital innovation, and megaproject delivery. It is the author's expectation that discussions presented here on the four grand challenges could be useful to inform further research and development at the Frontiers of Construction Management for the dependable built environment.

\section{Contributions}

The main contribution of this article is to provide an initial description about four identified grand challenges in construction management together with regard to further 
research and development under practice oriented strategies at various scales. In order to detail the four grand challenges in relation to leadership development and capability growth for the goals on both dependability and productivity in the provision of construction management services, this article has attempted to clarify four related issues for the advancement of construction management profession, and these include:

- A preliminary structure of cognitive domains of $\mathrm{CMBOK}$,

- The definition with a conceptual model of iCMS,

- A research and development strategy oriented review to further digital innovations under the three knowledge domains of CM, and

- A detailed summary on the structure and tools of using knowledge materials to inform further research and practices for leadership development as well as capability growth in megaproject delivery.

The structure adopted to derive the four grand challenges is generic and could be useful for further discussions on other grand challenges.

\section{Framework and Advantages}

The connections among research and development activates across the four grand challenges can form a generic framework to advance the construction management profession. These connections need to include the use of the proposed CMBOK framework as a guideline to develop iCMS, make and perform constant interdisciplinary digital innovations, and conduct improved megaproject management. In return, continuous outcomes and usages of new technical solutions from research and development in iCMS and interdisciplinary digital innovations, as well as megaproject management practice can provide new compounds of CMBOK. The reason for setting up these coherent connections is that it is an essential requirement for such intelligent systems as well as interdisciplinary digital innovations to be both applicable and useful in construction management practices, including those in megaproject delivery. It is therefore an important task for construction management professionals to specify decent connections to CMBOK when a new technical solution is to be developed and adopted. The advantages of using CMBOK framework to guide and connect research and development activities in construction management can be recognized from various sides, and these include standardizations in not only research and development but also professional services, the enrichment of professional knowledge, constant $\mathrm{CPD}$, and extensive interdisciplinary collaborations, etc.

\section{Limitations}

This article is based on the author's literature review and observations in construction management, and these were used in discussions on the four grand challenges through qualitative analysis. Although reviewers' comments have hugely helped him to conduct further research in order to illustrate a more vivid landscape with regard to the four identified grand challenges in construction management, there is limited time for him to make the description comprehensive with more details in both qualitative and quantitative way. Further research is inevitably necessary so as to not only describe the four grand challenges in more details, but also identify more technical challenges inside different scopes so as to pursue excellent professional services in construction management.

\section{Remarks}

Climate change and variability has been giving challenges to construction management professionals around the world over the past century (Stehr and von Storch, 2000). In the pursuit of dependability and productivity of professional services in the life cycle of the built environment, professionals need to have thorough considerations upon constant interactions of complex variables between the built environment and the social environment within the natural environment in both short and longer term. While the four grand challenges discussed in this article were derived from a literature review on current national/regional strategies for the construction industry in world top economies, the author would like to recommend further research and development for long-term competence enhancement in areas relating to the four grand challenges, and these advances include:

- A national/regional $\mathrm{CMBOK}$ to support the provision of construction management services in the ear of Industry 4.0 , and it can be used to develop relevant standards for construction management,

- Knowledge-driven solutions for thorough use of DIK within an immersive environment for construction management, and

- Techniques and tools for construction management incorporating with site automation, and

- Theories, techniques and tools to tackle overrun problems in megaproject management.

\section{ABOUT THE AUTHOR}

The author is specialty chief editor for the Construction Management section of Frontiers in Built Environment. He has relevant experiences accumulated from academic and professional services worldwide since later 1980s. He has engaged in more than 50 funded research projects totalling over $£ 5 \mathrm{~m}$ from research councils and industry partners in UK and internationally. In collaborations with colleagues worldwide, he has made contributions to more than 200 publications, including more than 50 publications collected on the Web of Science (Researcher ID C-1587-2010), in addition to some other publications collected at ORCID 0000-0003-0212-1140 and Google Scholars. He is member of the management committee of COST Action TU1003 (20112015) for research into the effective design and delivery of megaprojects in the European Union. He serves as member at several relevant technical committees, including committees on Airport Planning and Operations, and the CEBOK, respectively, at ASCE, and committees on Facilities Management, and 
Project, Programme and Portfolio Management, respectively, at BSI.

\section{AUTHOR CONTRIBUTIONS}

The author confirms being the sole contributor of this work and has approved it for publication.

\section{ACKNOWLEDGMENTS}

This article is prepared for the launch of the specialty section on construction management at the international open-access journal of Frontiers in Built Environment. The author would like to thank Professor Izuru Takewaki, the Chief Editor of the Frontiers in Built Environment for huge support in developing the specialty section on Construction Management. Ruth Miller, Journal Development Manager; Emily Young, and Sarah Yardley, Journal Development Specialists; and other colleagues at Frontiers have all provided strong support and thorough help in the establishment of this specialty section and its research topics. Special thanks to Nicholas Fraser, former Journal Development Manager at Frontiers, for the development of the new specialty section at initial stage. The author would also like to thank all colleagues on the editorial board as either Associate Editor or Review Editor for their strong support and contributions to the specialty section on Construction Management. The author would like to express special thanks to Dr. Conor Mooney at the Council of Europe Development Bank for his strong support as Associate Editor to the establishment of this specialty section at Frontiers in Built Environment.

The author is deeply grateful to his mentors and colleagues from both academia and industry around the world for their help and giving him great opportunities to learn from them more or less in the past three decades. His learning experience with them are extensive, useful, and inspiring.

\section{REFERENCES}

ACCE (2017). Annual Report 2016-2017. San Antonio, TX: The American Council for Construction Education (ACCE).

Alarcón, L. (1997). Lean Construction. London: CRC Press.

Allee, V. (1997). The Knowledge Evolution: The Knowledge Evolution: Expanding Organizational Intelligence. Newton, MA: Butterworth-Heinemann.

Allplan (2018). Intelligent Cost Management. München: Allplan Deutschland GmbH. Available online at: https://www.allplan.com/fileadmin/user_upload/ countries/international/pdfs/references/Design2Cost_CaseStudy_ElwertGrundschule_EN.pdf (accessed September 23, 2018).

Alonso, A., Dallmeier, F., and Servat, G. P. (2013). Monitoring Biodiversity: Lessons from a Trans-Andean Megaproject. Washington, DC: Smithsonian Institution Scholarly Press.

AlSehaimi, A., Koskela, L., and Tzortzopoulos, P. (2013). Need for alternative research approaches in construction management: case of delay studies. J. Manag. Eng. 29:4. doi: 10.1061/(ASCE)ME.1943-5479.0000148

Anumba, C. J., Egbu, C. O., and Carrillo, P. M. (2005). Knowledge Management in Construction. Oxford: Blackwell Publishing Ltd.

Arditi, D., and Polat, G. (2010). Graduate education in construction management. J. Profession. Iss. Eng. Edu. Pract. 136:3. doi: 10.1061/(ASCE)EI.1943-5541.0000014
The unique opportunity that colleagues at Frontiers give to the author for this article focusing on grand challenges in construction management is huge inspirational for him to rethink about the research and development of construction management for both short and longer term.

This article was finalized at the Royal Society of Edinburgh where the author was attending the IDE (Institute of Demolition Engineers) Scottish Seminar in July 2018. It's an inspiring experience there for the author to further think about fundamental questions and answers in relation to the long-term leadership development and capability growth for considerate construction management to fulfill professional responsibilities on total project-oriented sustainability, which relies on a spur of engineering and management genius to spread enlightenment ideas among professionals so as to provide quality services that can support to create and sustain dependable built environment through project-oriented activities that have minimum adverse impacts to people and the nature.

This article cannot achieve the level of publication without a great amount of very insightful comments from reviewers. The author would like to acknowledge their help to make this publication possible. The author would also like to thank colleagues in the Review Operations Team and the Engineering Production Office at Frontiers for their efficient professional support.

For the specialty section on Construction Management at Frontiers in Built Environment, the author would like to invite colleagues working in either research or practice in related areas to come to share valuable experiences to foster further research and development worldwide. The more contributions from colleagues, the huge impacts that this specialty section can make to the long-term development of the construction management profession at national and international scope.

ASCE (2008). Civil Engineering Body of Knowledge for the 21st Century, 2nd Ed. Reston, VA: American Society of Civil Engineers (ASCE).

ASCE (2019). Civil Engineering Database. Reston, VA: American Society of Civil Engineers (ASCE).

Balfour Beatty (2017). Innovation 2050: A Digital Future for the Infrastructure Industry. London: Balfour Beatty plc.

BCA (2016). BIM for DfMA (Design for Manufacturing and Assembly) Essential Guide. Singapore: Building and Construction Authority (BCA).

Bechtel (2018). The Bechtel Report 2018. Reston, VA: Bechtel Corporation.

BEIS (2018). Industrial Strategy: Construction Sector Deal. London: Department for Business, Energy \& Industrial Strategy (BEIS).

Berechman, J. (2018). The Infrastructure We Ride On: Decision Making in Transportation Investment. Berlin: Palgrave Macmillan, Springer.

Bernold, L. E., and AbouRizk, S. M. (2010). Managing Performance in Construction. Hoboken, NJ: John Wiley \& Sons, Inc.

BGS (2012). Accessing Subsurface Knowledge-ASK Network. Edinburgh: British Geological Survey (BGS).

BIS (2013). Construction 2025: Industrial Strategy for Construction-Government and Industry in Partnership. London: Department for Business, Innovation \& Skills (BIS).

Black, E., and Pettitt, J. (2018). Boston Dynamics is Putting its Robotic Dog, Spot, to Work on Construction Sites. Tokyo: CNBC LLC. 
Blanco, J. L., Fuchs, S., Parsons, M., and Ribeirinho, M. J. (2018). Artificial Intelligence: Construction Technology's Next Frontier. New York, NY: McKinsey \& Company. Available online at: https://www.mckinsey.com/industries/ capital-projects-and-infrastructure/our-insights/artificial-intelligenceconstruction-technologys-next-frontier (accessed September 23, 2018).

BMUB (2016). Climate Action Plan 2050: Principles and Goals of the German Government's Climate Policy. Berlin: Federal Ministry for the Environment, Nature Conservation, Building and Nuclear Safety (BMUB).

BMWi. (2018). Federal Government Adopts Artificial Intelligence Strategy. Berlin: Federal Ministry for Economic Affairs and Energy (BMWi).

Boateng, P., Chen, Z., and Ogunlana, S. (2017). Megaproject Risk Analysis and Simulation: A Dynamic Systems Approach. Bingley: Emerald Publishing Limited.

Bock, T. (2015). The future of construction automation: technological disruption and the upcoming ubiquity of robotics. Automat. Construct. 59, 113-121. doi: 10.1016/j.autcon.2015.07.022

Bock, T., and Linner, T. (2016). Construction Robots: Elementary Technologies and Single-Task Construction Robots. Cambridge: Cambridge University Press.

Briesemeister, J. K. (2018). Managing Complex Construction Projects: A Systems Approach. New York, NY: Auerbach Publications.

Brookes, N., Chen, Z., and Lo Storto, C. (2012). International Journal of Architecture, Engineering and Construction. Special Issue on Planning and Managing Sustainable Infrastructural Megaprojects: Call for Papers. Available online at: http://www.iasdm.org/journals/download/call-for-papers-pmsim. pdf (accessed September 23, 2018).

Brookes, N., Chen, Z., and Lo Storto, C. (2014). Editorial: Special issue on infrastructure megaprojects. Int. J. Architect. Eng. Construct. 3:2. Available online at: http://www.iasdm.org/journals/index.php/ijaec/issue/view/10

Brookes, N., and Zhang, S. (2014). Call for Papers on Megaprojects: Global Similarities and Global Differences. Available online at: http:// blog.sciencenet.cn/blog-307182-823077.html (accessed September 23, 2018).

Browne, A. J. (2015). LAPSSET: The History and Politics of an Eastern African Megaproject. London: The Rift Valley Institute.

Brunn, S. D. (2011). Engineering Earth: The Impacts of Megaengineering Projects. Dordrecht: Springer.

BSI (2006). PD 6079-4:2006 Project Management. Guide to Project Management in the Construction Industry. London: The British Standards Institution (BSI).

BSI (2014). BS EN 60300-1:2014 Dependability Management-Part 1: Guidance for Management and Application. London: The British Standards Institution (BSI).

Campbell, S., De Beer, J., Van der Meulen, M., Mielby, S. B., Van Campenhout, I., Venvik, G. (2017). COST Action TU1206 Final Achievement Report. Belgium: COST Association.

Cardownie, S. (2017). Witness Statement of Steve Cardownie. Edinburgh: The Edinburgh Tram Inquiry.

Castro-Lacouture, D., Bryson, L. S., Maynard, C., Williams II, R. L., and Bosscher, P. (2007). "Concrete paving productivity improvement using a multi-task autonomous robot," in Proceedings of the 24th International Symposium on Automation and Robotics in Construction (ISARC) (Kochi), 223-228.

Chen, Q., García de Soto, B., and Adey, B. T. (2018a). Construction automation: research areas, industry concerns and suggestions for advancement. Automat. Construct. 94, 22-38. doi: 10.1016/j.autcon.2018.05.028

Chen, Z. (2007). Multi-criteria Decision-Making for the Sustainable Built Environment. Reading: University of Reading.

Chen, Z. (2017). "The principles of facilities management and case studies," in Proceedings of ARCOM and BEAM Centre Early Career Researcher and Doctoral Workshop on Building Asset Management, 2017-01-20. Glasgow: Glasgow Caledonian University.

Chen, Z. (2018). Standards Planning and Approval: Project Management Systems. Internal document. Project no. 9019-02604. London: British Standards Institution (BSI).

Chen, Z., Agapiou, A., and Smith, S. (2016). Themed issue on megaproject management: call for papers. Proc. ICE Manag. Procurement Law 171:2. doi: $10.13140 /$ RG.2.2.32373.37602

Chen, Z., Agapiou, A., and Smith, S. (2018b). Editorial: Themed issue on megaproject management. Proc. ICE Manag. Procurement Law 171:2. doi: 10.1680/jmapl.2018.171.2.43
Chen, Z., Chen, H., and Wang, C. (1999). An expert system for crack diagnosis in cast-in-place reinforced concrete structures (in Chinese). Construct. Technol. $28,24-25$.

Chen, Z., and Li, H. (2006). Environmental Management in Construction: A Quantitative Approach. London and New York, NY: Taylor \& Francis.

Chen, Z., Li, H., Kong, S. C. W., Hong, J., and Xu, Q. (2006a). E-commerce system simulation for construction and demolition waste exchange. Automat. Construct. 15, 706-718. doi: 10.1016/j.autcon.2005.09.003

Chen, Z., Li, H., Kong, S. C. W., and Xu, Q. (2006b). An analytic knowledge network process for construction entrepreneurship education. J. Manag. Dev. $25,11-27$.

Chen, Z., Maiti, S., and Agapiou, A. (2017). "Evidence-based safety management in building refurbishment," in Proceedings of International Research Conference (11-12/09/2017) (Salford: International Council for Research and Innovation in Building and Construction (CIB) and University of Salford), $119-128$.

Chen, Z., and Whitehead, C. (2015). "Call for papers: themed issue on megaproject sustainability," in Proceedings of the Institution of Civil EngineersEngineering Sustainability (London, UK).

Chen, Z., and Xu, W. (1996). Intelligent methods in building construction (in Chinese). Build. Construct. 18, 44-47.

Chou, J.-S., Lin, C.-W., Pham, A.-D., and Shao, J.-Y. (2015). Optimized artificial intelligence models for predicting project award price. Automat. Construct. 54, 106-115. doi: 10.1016/j.autcon.2015.02.006

CIOB (2014). Code of Practice for Project Management for Construction and Development, 5 th Ed. Oxford: Wiley-Blackwell.

CIOB (2015). Time and Cost Management Contract Suite. Ascot: The Chartered Institute of Building (CIOB).

CIOB (2018a). Overseas Accredited Institutions. Ascot: The Chartered Institute of Building (CIOB).

CIOB (2018b). Improving Quality in the Built Environment. Ascot: The Chartered Institute of Building (CIOB).

CIOB (2018c). Guide to Good Practice in the Management of Time in Major Projects: Dynamic Time Modelling, 2nd Ed. Oxford: Wiley-Blackwell.

CIOB (2018d). Accident Investigation and Root Cause Analysis. Ascot: The Chartered Institute of Building (CIOB).

CIOB. (2010). CIOB's Professionalism: An Inclusive Definition of Construction Management. Ascot: Chartered Institute of Building (CIOB).

Clarivate (2019). Web of Science. London: Clarivate Analytics.

Croft, C., Buck, M., and Adams, S. (2016). Lessons Learned from Structuring and Governance Arrangements: Perspectives at the Construction Stage of Crossrail. London: Crossrail Ltd.

Crossrail (2018). Crossrail Learning Legacy. London: Crossrail Ltd.

CSIC (2017). Annual Review 2017. Cambridge: The Cambridge Centre for Smart Infrastructure and Construction (CSIC).

Dalkir, K. (2017). Knowledge Management in Theory and Practice, 3rd Ed. Cambridge, MA: The MIT Press.

Davies, A., Gann, D., and Douglas, T. (2009). Innovation in megaprojects: systems integration at London Heathrow Terminal 5. California Manag. Rev. 51, 101-125. doi: $10.2307 / 41166482$

De Laubier, R., Wunder, M., Witthöft, S., and Rothballer, C. (2018). Will $3 D$ Printing Remodel the Construction Industry? Boston, MA: The Boston Consulting Group (BCG).

DHS (2012). Office of Infrastructure Protection Strategic Plan: 2012-2016. Washington, DC: U.S. Department of Homeland Security (DHS).

DHS (2013). NIPP 2013: Partnering for Critical Infrastructure Security and Resilience. Washington, DC: U.S. Department of Homeland Security (DHS).

Dong, J., Tang, L., Gong, W., Utili, S., and Crosta, G. (2018). Special Issue on Mega Engineering Projects in Challenging Geological Environments-A Modern Perspective: Call for Papers. Elsevier.

DOT (2018). Strategic Plan for FY 2018-2022. Washington, DC: U.S. Department of Transportation (DOT).

EC (2012). Strategy for the Sustainable Competitiveness of the Construction Sector and its Enterprises. Communication from the Commission to the European Parliament and the Council. Brussels: European Commission (EC).

Elecosoft (2018). Powerproject: The Power Behind Successful Projects. Haddenham: Elecosoft UK Ltd.

EMAP (2017). CN Specialists Index 2017. London: EMAP Ltd. 
EMAP (2018). Construction Industry Company League Tables. London: EMAP Ltd. ENR (2018). ENR 2018 Top 400 Contractors. New York, NY: Engineering NewsRecord (ENR).

EPA (2017). Policy on Water Infrastructure Sustainability. Washington, DC: United States Environmental Protection Agency (EPA).

ESRI (2002). GIS Solutions for Community Development. Redlands, CA: ESRI.

ESRI (2007). GIS Solutions for Surveying. Redlands, CA: ESRI.

ESRI (2008). GIS Solutions for Civil Engineering. Redlands, CA: ESRI.

ETI (2018). Edinburgh Tram Inquiry: Evidence. Edinburgh: The Edinburgh Tram Inquiry (ETI).

Eynon, J. (2013). The Design Manager's Handbook. Chichester: John Wiley \& Sons Ltd.

Eynon, J. (2016). Construction Manager's BIM Handbook. Chichester: John Wiley and Sons Ltd.

Fadaee, S., and Schindler, S. (2017). Call for Papers on Megaprojects. Environment and Society: Advances in Research. Oxford, UK: Berghahn Books.

Faro (2019). BuildIT Construction. Lake Mary, FL: FARO Technologies, Inc.

FHWA (2017). e-Construction and Partnering: A Vision for the Future. Federal Highway Administration (FHWA), U. S. Departments of Transportation (DOT).

Fischer, M., Rajagopal, R., and Nikkhoo, P. (2018). Any Time Data Thinking Prototype for Construction Project Managers. Stanford, CA: Stanford Center for Integrated Facility Engineering (CIFE).

Flyvbjerg, B. (2015). Call for papers-special issue on "Classics in Megaproject Management". Int. J. Project Manag. 33, 1-2. doi: 10.1016/j.ijproman.2014.08.002

Flyvbjerg, B. (2017). The Oxford Handbook of Megaproject Management. Oxford: Oxford University Press.

Flyvbjerg, B., Bruzelius, N., and Rothengatter, W. (2003). Megaprojects and Risk: An Anatomy of Ambition. Cambridge: Cambridge University Press.

Flyvbjerg, B., and Turner, J. R. (2018). Do classics exist in megaproject management? Int. J. Project Manag. 36, 334-341. doi: 10.1016/j.ijproman.2017.07.006

Frick, K. T. (2016). Remaking the San Francisco-Oakland Bay Bridge: A Case of Shadowboxing with Nature. Abingdon and New York, NY: Routledge.

Future Cities Catapult (2017). Underground Asset Mapping in the UK. London: Urban Innovation Centre.

Galloway, P. D., Nielsen, K. R., and Dignum, J. L. (2012). Managing Gigaprojects: Advice from Those Who've Been There, Done That. Reston, VA: American Society of Civil Engineers (ASCE).

García de Soto, B., Agustí-Juan, I., Hunhevicz, J., Joss, S., Graser, K., Habert, G., et al. (2018). Productivity of digital fabrication in construction: cost and time analysis of a robotically built wall. Automat. Construct. 92, 297-311. doi: 10.1016/j.autcon.2018.04.004

Gil, N., Lundrigan, C., Pinto, J. K., and Puranam, P. (2017). MegaProject Organization and Performance: The Myth and Political Reality. Newtown Square, PA: Project Management Institute, Inc.

Grahovac, D., and Devedzic, V. (2010). COMEX: a cost management expert system. Expert Syst. Appl. 37, 7684-7695. doi: 10.1016/j.eswa.2010. 04.073

Greiman, V. A. (2013). Megaproject Management: Lessons on Risk and Project Management from the Big Dig. Hoboken, NJ: John Wiley and Sons, Inc.

Griffith, A. (2010). Integrated Management Systems for Construction: Quality, Environment and Safety. London: Routledge.

Guo, C., and Sheng, Z. (2017). Infrastructure Mega-Project Management: Call for Papers. Beijing: Higher Education Press.

Hagan, G., Baltov, M., and Brookes, N. (2012). Megaproject management: the state of the art. Organ. Technol. Manag. Construct. 4, 567-569.

Hardin, B., and McCool, D. (2015). BIM and Construction Management: Proven Tools, Methods, and Workflows, 2nd Ed. Indianapolis, IN: John Wiley and Sons, Inc.

Hart, L. (2015). Procuring Successful Mega-Projects: How to Establish Major Government Contracts without Ending up in Court. Surrey: Gower Publishing Ltd.

Harty, C. (2005). Innovation in construction: a sociology of technology approach. Build. Res. Info. 33, 512-522. doi: 10.1080/0961321050028860
Hatem, D. J., and Corkum, D. H. (2010). Megaprojects: Challenges and Recommended Practices. Washington, DC: American Council of Engineering Companies.

Hawksworth, J., Berriman, R., and Goel, S. (2018). An International Analysis of the Potential Long Term Impact of Automation. London, UK: PricewaterhouseCoopers LLP.

HSE (2015). Managing health and Safety in Construction: Construction (Design and Management) Regulations 2015. Bootle: Health and Safety Executive (HSE).

HURD (2017). The 13th Five-Year Plan for Construction Industry Development. Beijing: Ministry of Housing and Urban-Rural Development (HURD) of the People's Republic of China.

ICE (2019). ICE Library. London: Institution of Civil Engineers (ICE).

IPA (2016). Government Construction Strategy: 2016-2020. London: The Infrastructure and Projects Authority (IPA).

ISO (2008). ISO 22263:2008 Organization of Information about Construction Works-Framework for Management of Project Information. Geneva: International Organization for Standardization (ISO).

ISO (2009a). ISO/TR 16738:2009 Fire-Safety Engineering-Technical Information on Methods for Evaluating Behaviour and Movement of People. Geneva: International Organization for Standardization (ISO).

ISO (2009b). ISO 23601:2009 Safety Identification-Escape and Evacuation Plan Signs. Geneva: International Organization for Standardization (ISO).

ISO (2011). ISO 21542:2011 Building Construction-Accessibility and Usability of the Built Environment. Geneva: International Organization for Standardization (ISO).

ISO (2012). ISO 21500:2012 Guidance on Project Management. Geneva: International Organization for Standardization (ISO).

ISO (2013). ISO 16354:2013 Guidelines for Knowledge Libraries and Object Libraries. Geneva: International Organization for Standardization (ISO).

ISO (2015a). ISO 9001:2015 Quality Management Systems-Requirements. Geneva: International Organization for Standardization (ISO).

ISO (2015b). ISO/TS 22318:2015 Societal Security-Business Continuity Management Systems-Guidelines for Supply Chain Continuity. Geneva: International Organization for Standardization (ISO).

ISO (2017a). ISO and Construction. Geneva: International Organization for Standardization (ISO).

ISO (2017b). ISO 15686-5:2017 Buildings and Constructed Assets-Service Life Planning-Part 5: Life-cycle Costing. Geneva: International Organization for Standardization (ISO).

ISO (2017c). ISO 44001:2017 Collaborative Business Relationship Management Systems-Requirements and Framework. Geneva: International Organization for Standardization (ISO).

ISO (2017d). ISO 20400:2017 Sustainable Procurement-Guidance. Geneva: International Organization for Standardization (ISO)

ISO (2018a). Standards Catalogue: ISO/TC 59/SC 13 Organization and Digitization of Information about Buildings and Civil Engineering Works, Including Building Information Modelling (BIM). Geneva: International Organization for Standardization (ISO).

ISO (2018b). Standards Catalogue: ISO/TC 59/SC 18 Construction Procurement. Geneva: International Organization for Standardization (ISO).

ISO (2018c). Standards Catalogue: ISO/TC 59/SC 14 Design life. Geneva: International Organization for Standardization (ISO).

ISO (2018d). Standards Catalogue: ISO/TC 59/SC 17 Sustainability in Buildings and Civil Engineering Works. Geneva: International Organization for Standardization (ISO).

ISO (2018e). Standards Catalogue: ISO/TC 267 Facility Management. Geneva: International Organization for Standardization (ISO).

ISO (2018f). The Integrated Use of Management System Standards. Geneva: International Organization for Standardization (ISO).

ISO (2018g). ISO 31000:2018 Risk Management-Guidelines. Geneva: International Organization for Standardization (ISO).

ISO (2018h). ISO 22326:2018 Security and Resilience-Emergency ManagementGuidelines for Monitoring Facilities with Identified Hazards. Geneva: International Organization for Standardization (ISO).

ISO (2018i). Standards Catalogue: ISO/TC 92 Fire Safety. Geneva: International Organization for Standardization (ISO) 
ISO (2018j). Standards Catalogue: ISO/TC 195 Building Construction Machinery and Equipment. Geneva: International Organization for Standardization (ISO).

ISO (2018k). Standards Catalogue: ISO/TC 260 Human Resource Management. Geneva: International Organization for Standardization (ISO).

ISO (20181). Standards Catalogue: ISO/TC 46 Information and Documentation. Geneva: International Organization for Standardization (ISO).

ISO (2018m). Standards Catalogue: ISO/TC 207 Environmental Management. Geneva: International Organization for Standardization (ISO).

ISO (2018n). Standards Catalogue: ISO/TC 269 Railway Applications. Geneva: International Organization for Standardization (ISO).

ISO (20180). Standards Catalogue: ISO/TC 301 Energy Management and Energy Savings. Geneva: International Organization for Standardization (ISO).

ISO (2018p). Standards Catalogue: ISO/TC 258 Project, Programme and Portfolio Management. Geneva: International Organization for Standardization (ISO).

Jia, G., Ni, X., Chen, Z., Hong, B., Chen, Y., Yang, F., et al. (2013). Measuring the maturity of risk management in large-scale construction projects. Automat. Construct. 34, 56-66. doi: 10.1016/j.autcon.2012. 10.015

Jones, G. R., and George, J. M. (2016). Essentials of Contemporary Management, 7 th Ed. New York, NY: McGraw-Hill Education.

Kajima (2018). Kajima Corporate Report 2018. Tokyo: Kajima Corporation.

Kim, W. C., and Mauborgne, R. (2004). Blue Ocean Strategy. Brighton, MA: Harvard Business Review Press.

Kostka, G., and Fiedler, J. (2016). Large Infrastructure Projects in Germany: Between Ambition and Realities. Berlin: Palgrave Macmillan, Springer.

Kwegyir-Afful, C. (2018). Delivering Successful Megaprojects: Key Factors and Toolkit for the Project Manager. Amington: KAPM Services Limited.

Kwon, N., Park, M., Lee, H.-S., Ahn, J., and Kim, S. (2017). Construction noise prediction model based on case-based reasoning in the preconstruction phase. J. Construct. Eng. Manag. 143:04017008. doi: 10.1061/(ASCE)CO.1943-7862.0001291

Laing O'Rourke (2017) Annual Report and Consolidated Financial Statements for the Year Ended 31 March 2017. Dartford: Laing O’Rourke.

Lehtonen, M., Joly, P. B., and Aparicio, L. (2017) Socioeconomic Evaluation of Megaprojects: Dealing with Uncertainties. London: Routledge.

LGA (2018). National Construction Category Strategy 2018. London: Local Government Association (LGA).

Li, H., Chan, N., Huang, T., Guo, H.L., Lu, W., and Skitmore, M. (2009). Optimizing construction planning schedules by virtual prototyping enabled resource analysis. Automat. Construct. 18, 912-918. doi: 10.1016/j.autcon.2009.04.002

Li, H., Chen, Z., Yong, L., and Kong, S.C.W. (2005). Application of integrated GPS and GIS technology for reducing construction waste and improving construction efficiency. Automat. Construct. 14, 323-331. doi: 10.1016/j.autcon.2004.08.007

Li, H., and Guo, H. L. (2011). Editorial: Special issue on "Complexities in managing mega construction projects". Int. J. Proj. Manag. 29, 795-796.

Li, Y., Lu, Y., and Cui, Q. (2016). Organizational Behaviour and Governance of Megaprojects: Call for Papers. Reston, VA: American Society of Civil Engineers (ASCE).

Locatelli, G., Gatti, S., van Marrewijk, A., and Pitsis, T. S. (2017). Call for Papers: The Present and Future of Contracting and Megaprojects. London, UK: SAGE Publications.

Love, P. E. D., and Li, H. (1998). From BPR to CPR-conceptualising re-engineering in construction. Business Process Manag. J. 4, 291-305. doi: 10.1108/14637159810238192

Luk, S., and Whitney, J. (1993). Megaproject: Case Study of China's Three Gorges Project. London: M. E. Sharpe, Inc.

Luo, H., Xiong, C., Fang, W., Love, P. E. D., Zhang, B., and Xi, O. (2018). Convolutional neural networks: computer vision-based workforce activity assessment in construction. Automat. Construct. 94, 282-289. doi: 10.1016/j.autcon.2018.06.007

Mascia, S. (2012). Project Psychology. London: Routledge.

MedSolutions (2013). Why Intelligent Cost Management? Bluffton, SC: eviCore healthcare.

Merrow, E. W. (2011). Industrial Megaprojects: Concepts, Strategies, and Practices for Success. Hoboken, NJ: John Wiley and Sons, Inc.
Merrow, E. W., and Nandurdikar, N. S. (2018). Leading Complex Projects: A Data-Driven Approach to Mastering the Human Side of Project Management. Hoboken, NJ: John Wiley and Sons, Inc.

Microsoft (2016). Reimagine Productivity with Microsoft Dynamics 365. Redmond, WA: Microsoft Corporation.

Morris, P. W. G. (2013). Reconstructing Project Management. Chichester: John Wiley and Sons, Inc.

NASEM (2007). Emerging Technologies for Construction Delivery. National Academies of Sciences, Engineering, and Medicine (NASEM). Washington, DC: The National Academies Press.

NBS Research (2018). Digital Transformation in Architecture. Microsoft Corporation and the Royal Institute of British Architects (RIBA).

Nguyen, L. D., Chih, Y.-Y., and García de Soto, B. (2017). Knowledge areas delivered in project management programs: exploratory study. J. Manag. Eng. 33:1. doi: 10.1061/(ASCE)ME.1943-5479.0000473

Norris, E., Rutter, J., and Medland, J. (2013). Making the Games: What Government can Learn from London 2012. London: Institute for Government.

Nunamaker, J. Jr, Briggs, R., and Romano, N. Jr. (2014). Collaboration Systems. New York, NY: Routledge.

Oakland, J., and Marosszeky, M. (2017). Total Construction Management. London: Routledge.

Ochieng, E., Price, A., and Moore, D. (2017). Major Infrastructure Projects: Planning for Delivery. London: Palgrave.

ODA (2011). Lessons Learned from the London 2012 Construction Project. London: Olympic Delivery Authority (ODA).

ODA (2015). Olympic Delivery Authority (ODA). London: Department for Culture, Media and Sport. Available online at: https://www.gov.uk/government/ organisations/olympic-delivery-authority

ONS (2009). UK Standard Industrial Classification of Economic Activities 2007 (SIC 2007): Structure and Explanatory Notes. Hampshire: Palgrave Macmillan.

Osterwalder, A., Pigneur, Y., Bernarda, G., Smith, A., and Papadakos, T. (2014). Value Proposition Design: How to Create Products and Services Customers Want. Hoboken, NJ: John Wiley and Sons.

Pellicer, E., Yepes, V., and Ortega, A. J. (2013). Method for planning graduate programs in construction management. J. Profession. Iss. Eng. Edu. Pract. 139:1. doi: 10.1061/(ASCE)EI.1943-5541.0000120

Pells, D. (2014). Call for Papers on Planning and Managing Infrastructure Megaprojects. Addison, TX: PM World Inc. Available online at: http://promaconafrica.org/index.php/2014/08/30/call-for-papers-onmanaging-infrastructure-megaprojects/ (accessed February 27, 2019).

Plotch, P. M. (2015). Politics across the Hudson: The Tappan Zee Megaproject. New Brunswick: Rutgers University Press.

PMI (2016). Construction Extension to the PMBOK ${ }^{\circledR}$ Guide. Newtown Square, PA: Project Management Institute (PMI).

PMI (2017). A Guide to the Project Management Body of Knowledge (PMBOK ${ }^{\circledR}$ Guide), 6th Ed. Newtown Square, PA: Project Management Institute (PMI).

PricewaterhouseCoopers. (2014). Successful Capital Project Delivery: The Art and Science of Effective Governance. San Francisco, CA: PricewaterhouseCoopers LLP.

Priemus, H., Flyvbjerg, B., and van Wee, B. (2008). Decision-making on MegaProjects: Cost-benefit Analysis, Planning, and Innovation. Cheltenham: Edward Elgar Publishing.

Priemus, H., and van Wee, B. (2013). International Handbook on Mega-Projects. Cheltenham: Edward Elgar Publishing.

Pryke, S. (2017). Managing Networks in Project-Based Organisations. Oxford: John Wiley and Sons Ltd.

Rafiei, M. H., and Adeli, H. (2018). Novel machine-learning model for estimating construction costs considering economic variables and indexes. J. Construct. Eng. Manag. 144:04018106. doi: 10.1061/(ASCE)CO.1943-7862.0001570

Ren, H. (2012). Megaproject Management (in Chinese). Beijing: Science Press.

RIBA (2013). RIBA Plan of Work 2013 Overview. London: The Royal Institute of British Architects (RIBA).

RICS (2018). RICS Accredited Course. London: Royal Institution of Chartered Surveyors (RICS).

Rios, F. C., Chong, W. K., and Grau, D. (2015). Design for disassembly and deconstruction-challenges and opportunities. Procedia Eng. 118, 1296-1304. doi: 10.1016/j.proeng.2015.08.485 
Rossi, E., and Stepic, R. (2015). Infrastructure Project Finance and Project Bonds in Europe. Basingstoke: Palgrave Macmillan.

Rumane, A. R. (2018). Quality Management in Construction Projects, 2nd Ed. Boca Raton, FL: CRC Press.

Russell, S., and Norvig, P. (2010). Artificial Intelligence: A Modern Approach, 3rd Ed. Upper Saddle River, NJ: Pearson Education, Inc.

Saaty, T. L. (1996). Decision making with Dependence and Feedback: The Analytic Network Process. Pittsburgh, PA: RWS Publications.

Santamaría, G. C. (2013). Urban Megaprojects: A Worldwide View. Bingley: Emerald Publishing Limited.

Scottish Parliament (2005). Building the Scottish Parliament: The Holyrood Project. Edinburgh: Scottish Parliament.

Shen, L., Zeng, S., and Tam, V. W.Y. (2017). Special edition: social responsibilities for the management of megaprojects. Int. J. Proj. Manag. 35, 1336-1337. doi: 10.1016/j.ijproman.2017.06.001

Sheng, Z. (2018). Fundamental Theories of Mega Infrastructure Construction Management: Theoretical Considerations from Chinese Practices. Cham: Springer.

Singh, A., and Ebeling, K. (1994). Construction process simulation using a standardized configuration and model. Proj. Manag. J. 25, 45-52.

Skanska (2018). Annual Report 2017. Stockholm: Skanska AB.

Skibniewski, M. J. (1988). Framework for decision-making on implementing robotics in construction. J. Comput. Civil Eng. 2:2. doi: 10.1061/(ASCE)0887-3801(1988)2:2(188)

Smith, D. (2018). Artificial Intelligence Enabling Machines to Learn: Experts Perspectives. London: Arup.

Söderlund, J., Sankaran, S., and Biesenthal, C. (2016). Call for Papers: Special Issue on Megaprojects-Symbolic and Sublime: An Organizational Theory Perspective. Newtown Square, PA: Project Management Institute, Inc.

Sovacool, B. K., and Cooper, C. J. (2013). The Governance of Energy Megaprojects: Politics, Hubris and Energy Security. Cheltenham and Northampton, MA: Edward Elgar Publishing.

Stehr, N., and von Storch, H. (2000). Eduard Brückner-The Sources and Consequences of Climate Change and Climate Variability in Historical Times. Heidelberg: Springer.

Sterman, J. D. (1992). System Dynamics Modeling for Project Management. Cambridge, MA: Massachusetts Institute of Technology.

STI (2017a). Comprehensive Strategy on Science, Technology and Innovation for 2017. Tokyo: Council for Science, Technology and Innovation (STI).

STI (2017b). Integrated Innovation Strategy. Tokyo: Council for Science, Technology and Innovation (STI).

Taylor, F. W. (1911). The Principles of Scientific Management. New York and London: Harper and Brothers Publishers.

The Press Office (2013). Presidential Policy Directive-Critical Infrastructure Security and Resilience. Washington, DC: The White House Office of the Press Secretary (The Press Office).

Thorpe, B., and Sumner, P. (2004). Quality Management in Construction. Aldershot: Gower Publishing, Ltd.
Tixier, A., Hallowell, M. R, Rajagopalan, B., and Bowman, D. (2016). Automated content analysis for construction safety: a natural language processing system to extract precursors and outcomes from unstructured injury reports. Automat. Construct. 62. 45-56. doi: 10.1016/j.autcon.2015.11.001

Walker, A. (2015). Project Management in Construction, 6th Ed. Chichester: John Wiley and Sons Ltd.

Walker, D. H. T. (2016). Reflecting on 10 years of focus on innovation, organisational learning and knowledge management literature in a construction project management context. Construct. Innovat. 16, 114-126. doi: 10.1108/CI-12-2015-0066

Wang, X., Chong, H.-Y., and Kwak, Y. H. (2017). Special collection announcement: supply chain management in megaprojects. J. Manag. Eng. 33:4. doi: 10.1061/(ASCE)ME.1943-5479.0000516

Wang, Z., Li, H., and Zhang, X. (2019). Construction waste recycling robot for nails and screws: computer vision technology and neural network approach. Automat. Construct. 97, 220-228. doi: 10.1016/j.autcon.2018. 11.009

Waziri, B. S., Bala, K., and Bustani, S. (2017). Artificial neural networks in construction engineering and management. Int. J. Architect. Eng. Construct. 6, 50-60. doi: 10.7492/IJAEC.2017.006

Wegrich, K., Kostka, G., and Hammerschmid, G. (2017). The Governance of Infrastructure. Oxford: Oxford University Press.

Whyte, J., and Nikolić, D. (2018). Virtual Reality and the Built Environment, 2nd Ed. Abingdon: Routledge.

Winch, G. M. (2009). Managing Construction Projects, 2nd Ed. Chichester: John Wiley and Sons Ltd.

Womack, J. P., and Jones, D. T. (1996). Lean Thinking: Banish Waste and Create Wealth in Your Corporation. New York, NY: Simon and Schuster.

$\mathrm{Wu}$, C., Chen, D., and Huang, S. (2018). Complexity of Construction Mega Infrastructure Project: Call for Papers. London: Hindawi Publishing Corporation.

Xu, W., and Chen, Z. (1997). Intelligent Methods in Construction. Shanghai: Tongji University Press.

Yang, J. (2017). Environmental Management in Mega Construction Projects. Singapore: Springer.

Yeung, C.L., Cheung, C.F., Wang, W.M., and Tsui, E. (2014). A knowledge extraction and representation system for narrative analysis in the construction industry. Expert Syst. Appl. 41, 5710-5722. doi: 10.1016/j.eswa.2014.03.044

Conflict of Interest Statement: The author declares that the research was conducted in the absence of any commercial or financial relationships that could be construed as a potential conflict of interest.

Copyright (c) 2019 Chen. This is an open-access article distributed under the terms of the Creative Commons Attribution License (CC BY). The use, distribution or reproduction in other forums is permitted, provided the original author $(s)$ and the copyright owner(s) are credited and that the original publication in this journal is cited, in accordance with accepted academic practice. No use, distribution or reproduction is permitted which does not comply with these terms. 